IZA DP No. 7229

Does Forced Solidarity Hamper Investment in Small and Micro Enterprises?

Michael Grimm

Renate Hartwig Jann Lay

February 2013 


\title{
Does Forced Solidarity Hamper Investment in Small and Micro Enterprises?
}

\author{
Michael Grimm \\ University of Passau, \\ Erasmus University Rotterdam and IZA \\ Renate Hartwig \\ University of Passau \\ and Erasmus University Rotterdam \\ Jann Lay \\ GIGA - German Institute of Global and Area Studies, Hamburg \\ and University of Göttingen
}

\author{
Discussion Paper No. 7229 \\ February 2013
}

\author{
IZA \\ P.O. Box 7240 \\ 53072 Bonn \\ Germany \\ Phone: $+49-228-3894-0$ \\ Fax: +49-228-3894-180 \\ E-mail: iza@iza.org
}

\begin{abstract}
Any opinions expressed here are those of the author(s) and not those of IZA. Research published in this series may include views on policy, but the institute itself takes no institutional policy positions. The IZA research network is committed to the IZA Guiding Principles of Research Integrity.

The Institute for the Study of Labor (IZA) in Bonn is a local and virtual international research center and a place of communication between science, politics and business. IZA is an independent nonprofit organization supported by Deutsche Post Foundation. The center is associated with the University of Bonn and offers a stimulating research environment through its international network, workshops and conferences, data service, project support, research visits and doctoral program. IZA engages in (i) original and internationally competitive research in all fields of labor economics, (ii) development of policy concepts, and (iii) dissemination of research results and concepts to the interested public.
\end{abstract}

IZA Discussion Papers often represent preliminary work and are circulated to encourage discussion. Citation of such a paper should account for its provisional character. A revised version may be available directly from the author. 


\section{ABSTRACT \\ Does Forced Solidarity Hamper Investment in Small and Micro Enterprises? ${ }^{1}$}

Sharing is a norm in many societies. We present a theoretical model on the trade-off between sharing and investment which we test on data from tailors in Burkina Faso. The empirical results support the idea that there are two behavioural patterns: entrepreneurs following an 'insurance regime' comply with sharing norms, are insured but reduce investment in their firm, whereas entrepreneurs in the 'growth regime' are not insured but take undistorted investment decisions. The choice of regime depends on the redistributive pressure, the willingness to take risk, and the return on investment.

JEL Classification: D13, D22, D92, O12, O43

Keywords: forced solidarity, informal insurance, investment, micro and small enterprises, sharing, Sub-Saharan Africa

Corresponding author:

Michael Grimm

University of Passau

Innstrasse 29

94032 Passau

Germany

E-mail: michael.grimm@uni-passau.de

\footnotetext{
${ }^{1}$ We thank Myriam Hadnes for her field work related to the collection of the data used in this paper. Moreover we are grateful for valuable comments made by Jenny Aker, Francisco Ferreira, Ingrid Kubin, Michael Pflüger and Johann Graf Lambsdorff as well as comments received at the CSAE Conference in Oxford, the IZA and World Bank Employment and Development Conference in Delhi, the Micro-insurance Conference in Twente, the PEGNet Conference in Hamburg, the VfS DevEcon Conference in Bonn, the VfS Population Economics Workshop in St. Gallen and at seminars held at the Erasmus University Rotterdam, the University of Göttingen, the University of Munich, the University of Osnabrück and the Rheinisch-Westfälisches Institut für Wirtschaftsforschung (RWI) in Essen.

The research in this paper is part of a project entitled "Unlocking potential: Tackling economic, institutional and social constraints of informal entrepreneurship in Sub-Saharan Africa" funded by the Austrian, German, Norwegian, Korean and Swiss Government through the World Bank's Multi Donor Trust Fund Project: "Labour Markets, Job Creation, and Economic Growth, Scaling up Research, Capacity Building, and Action on the Ground". Additional funding came from the German Development Bank as part of a project on "Employment and Empowerment". The financial support is gratefully acknowledged.
}

The findings, interpretations and conclusions expressed in this paper are entirely those of the authors. They do not necessarily represent the views of the World Bank, the German Development Bank and the donors supporting the Trust Fund. 


\section{Introduction}

Previous research has shown that micro and small entrepreneurs in poor countries achieve relatively high marginal returns to capital but show very low reinvestment rates (see e.g. McKenzie and Woodruff, 2006, 2008; De Mel et al., 2008; Kremer et al., 2010; Fafchamps et al., 2011; Grimm et al., 2011). The literature is rather inconclusive on the possible causes of the observed pattern. While capital market imperfections have been shown to be related to high marginal returns (McKenzie and Woodruff, 2006; De Mel et al., 2008), they do not explain why these returns are not retained and re-invested. Risk, as another factor, has also been associated with high returns, whereby low reinvestment rates are explained by households being required to hold on to cash if investments are largely irreversible (see e.g. Fafchamps and Pender, 1997). One aspect which has received less attention so far is whether obligations to share constitute an important cause of low re-investment rates.

In a context where people are frequently exposed to severe shocks but where the possibilities for smooth consumption are limited, sharing might be necessary to secure subsistence at all times. At the same time, sharing obligations or 'forced solidarity' might cause disincentive effects with regard to productive activities. Specifically, under strong sharing norms it may be difficult to save and invest in which case sharing obligations can become an important deterrent to economic growth and development.

The idea that family and kinship ties may imply adverse incentive effects on economic activity is relatively old in particular in the context of Sub-Saharan Africa. It was, for example, often mentioned in anthropological literature (see e.g. Barth, 1967) and was emphasized by modernisation theorists but with very different nuances and clearly distinguished conclusions (see e.g. Lewis, 1955; Meier and Baldwin, 1957; Bauer and Yamey, 1957; Hirschman, 1958; Rostow, 1960). Negative incentive effects are also discussed in the field of economic sociology and social network analysis as the downside of 'strong ties', which are often also referred to as 'bonding ties' (Granovetter, 1973, 1983, 1985; Barr, 2002).

More recently, the topic has been taken up again by a few economists (see, for example, Platteau, 2000; Hoff and Sen, 2006; Alger and Weibull, 2008, 2010). While acknowledging that family and kinship ties can be a vehicle for mutual insurance in contexts where formal insurance markets do not exist, 
these authors also argue that these ties may become an important obstacle in the process of economic transition when economically successful members within the kin may be confronted with sharing obligations by less successful ones. These obligations may require successful members to remit money, find jobs or host relatives in the city home (see, for example, Hoff and Sen, 2006). The main hypothesis that can be derived from these considerations is that these demands - or forced solidarity - can adversely affect the incentives of otherwise successful relatives to pursue and develop their economic activity. While opting out of the kinship network and refusing to comply with sharing obligations is possible, it may result in sanctions and high psychological costs (as in Hoff and Sen's (2006) model).

To date, there has been very little empirical backup for the existence of negative effects associated with family and kinship ties though there is some evidence that successful individuals do indeed tend to use various strategies to hide their income. Di Falco and Bulte (2011), for instance, find evidence that kinship size is associated with higher budget shares for non-shareable goods. Baland et al. (2011) analyse borrowing behaviour and find that some people take up credits even when they don't suffer from a liquidity constraint just to signal to their kin that they are unable to provide financial assistance. Brune et al. (2011) arrive at similar conclusions concerning saving, whereby commitment saving arrangements are found to lead to larger savings than ordinary saving arrangements. The authors explain the positive impact of commitment saving also with the desire to keep funds from being shared with one's kin. Adverse incentive effects due to redistributive pressure are also identified by Jakiela and Ozier (2012). They conducted lab-experiments in rural Kenyan villages in which they randomly vary the observability of investment returns to test whether subjects decide to hide income under certain conditions and indeed find that participants who know that the outcome of their investment will be made public, make decisions that are expected to be less profitable. Similar results are also reported in an experimental study by Hadnes et al. (2011) who find that sharing obligations and expectations on future demands for financial support lead to a significant reduction in labour input and productivity. In a real-life setting, Duflo et al. (2011), point to sharing obligations as one explanation why impatient Kenyan farmers forgo highly profitable investments in fertilizer. They argue that the impatience is partly rooted in the difficulty of protecting savings from consumption demands. Finally, Fafchamps (2002) also finds a negative 
association among agricultural traders in Madagascar between perceived 'fear of predation by relatives' and value added. ${ }^{2}$

Against this background, the purpose of this paper is to explicitly investigate whether family and kinship ties reduce the incentive and ability to invest in enterprise capital. We start from a theoretical model in which entrepreneurs have to decide whether they want to invest and rely on themselves or whether they share their income with their family and kin, hence forgo investment opportunities, but are insured against business and household-related shocks. A sanction that is imposed if sharing is refused, may force entrepreneurs to comply even if from their individual perspective investing would be the better alternative. In other words, sharing becomes the norm and can be interpreted as compulsory informal insurance, non-compliance with which is costly. Predictions derived from that model are then tested empirically using data on small and micro enterprises in Burkina Faso. Sharing norms are generally strong in the Burkinabè context, in particular within the ethnic group of the Mossi which is the dominant ethnicity in Ouagadougou (Fiske, 1990; Englebert, 1996).

It is important to note that in this paper we focus on family and kinship ties as opposed to social networks. The main difference between family and kinship ties, on the one hand, and the social network as a generic set of individuals who interact, on the other, is that family and kinship ties can be seen as largely exogenous and cannot be changed freely or only at high psychological costs (La Ferrara, 2007). There are hence different types of ties and the family and kinship network can be considered an important sub-network of the larger social network. This distinction largely overlaps with the distinction made in the field of economic sociology and social network analysis referring to 'weak' and 'strong ties' (Granovetter, 1973, 1983) whereby strong ties describe those links to the immediate family and kin and refer to rather closed networks.

The remainder of this paper is organised as follows. In Section 2 we develop a theoretical model of investment and transfers in a context of strong sharing obligations. In Section 3 we present the data and key variables. In Section 4 we translate the theoretical model into a set of structural equations to be estimated econometrically. In Section 5 we discuss the results and in Section 6 we conclude.

\footnotetext{
${ }^{2}$ However, this is not the focus of that paper and the results are not further discussed.
} 


\section{A model of investment under redistributive pres- sure}

Although our model is intended to have broader relevance, we call, in what follows, entrepreneurs simply 'tailors', as this group of entrepreneurs will be the subject of the empirical analysis later in the paper. The tailor operates in an urban setting. It is assumed that the tailor maximises the present value of expected utility over two consecutive periods. At the beginning of the first period, he has to decide if he wants to stay in his kinship network $(q=1)$. The network provides him with perfect insurance against a catastrophic shock $S$ that occurs with probability $\pi$ (with $0<\pi<1$ ) in each period. ${ }^{3}$ The loss $S$ and the distribution of $\pi$ is known to the tailor. In turn, the tailor has to pay remittances, $R$, to the kin at the end of period 1 . If the tailor decides to step out of the kinship network $(q=0)$, he has no insurance, does not have to pay $R$, but bears a disutility, $D$, in the first period. The disutility results from sanctions imposed on him because of the refused solidarity with the kin. Such sanctions may comprise of a loss of social status, harassment or the exclusion from ceremonies.

The tailor's expected welfare, $W$, is given by:

$$
W=\sum_{t=1}^{2} \beta^{t-1}\left[E\left(U\left(C_{t}\right)\right)\right]+(1-q) D .
$$

We assume that the underlying utility function is of the CRRA ${ }^{4}$ type which, in its most general form, can be written as follows:

$$
U=\frac{C^{(1-\theta)}}{1-\theta} \quad \text { with } 0<\theta<1,
$$

where the parameter $\theta$ measures the degree of the tailor's risk aversion.

$C_{t}$ stands for consumption, derived from income from productive activity $Y_{t}$ minus investment, $I$. In those cases in which the tailor remains in the kinship network ( $q=1)$, he remits $R$ and is not affected by the shock $S$. If he opts out, no remittances are made but the tailor may incur the financial loss related to a shock in period 2 . In period 1 , the tailor's consumption is hence:

$$
C_{1}=Y_{1}-I-q R
$$

\footnotetext{
${ }^{3}$ We think in particular of idiosyncratic shocks, such as catastrophic health expenditures, and ignore covariate shocks within the kin, which is plausible if the kinship network is geographically dispersed.

${ }^{4}$ Constant Relative Risk Aversion.
} 
and in period 2 the (expected) consumption is:

$$
E\left(C_{2}\right)=Y_{2}-(1-q) \pi S
$$

Output is produced using only capital, $K$. We focus on capital inputs in the model and in our empirical study although we acknowledge that the allocation of other inputs, in particular labour, may also be affected by kinship pressure. ${ }^{5}$ The tailor produces according to a standard neoclassical production function with standard properties, i.e. $f^{\prime}\left(K_{t}\right)>0, f^{\prime \prime}\left(K_{t}\right)<0, \lim _{K_{t} \rightarrow \infty} f^{\prime}\left(K_{t}\right)=0$ and $\lim _{K_{t} \rightarrow 0} f^{\prime}\left(K_{t}\right)=\infty$. Income is then given by:

$$
Y_{t}=f\left(K_{t}\right)
$$

The price of the goods produced by tailors is the numeraire and hence equal to one.

At the beginning of period 1 the tailor has a capital stock $K_{1} . K_{1}$ is exogenous and may differ across tailors. $K_{1}$ can only be used for production. It cannot be depleted or rented out. After period 1, the tailor can use his income to finance additional investment to adjust his capital stock in the second period, i.e.

$$
K_{2}=K_{1}+I .
$$

We make the strong, but not necessarily implausible, assumption that all tailors are credit constrained. ${ }^{6}$ Hence, any investment at the end of period 1 needs to be financed out of earnings.

The tailor's income in the first period is, however, not only the source of liquidity for investment, but also subject to remittances extracted by the kin through imposing a 'tax' on the tailor's income. The tax rate, $t$, is assumed to depend on the pressure for redistribution, $N$, which is in turn determined by the size of the kin that potentially seeks support. Pressure for redistribution may also be influenced by the intensity of sharing norms prevailing in the tailor's kin, the extent to which potential recipients behave as free-riders and the costs of observing the tailor's income. These factors are not explicitly modelled. It is important to note that $t$ is not a function of income, as it would probably be in a formal insurance system. The remittances, $R$, that have to be paid in

\footnotetext{
${ }^{5}$ For instance, an entrepreneur might be forced to employ (less productive) members of the kin.

${ }^{6}$ Indeed among the tailors interviewed in 2012 only $2.6 \%$ used a micro-finance or formal bank credit.
} 
cases where the tailor stays within the kinship network are hence given by:

$$
R=t(N) Y_{1} \quad \text { with } 0<t<1 \text {. }
$$

This formulation with a tax rate that does not take account of the network's welfare may imply that improvements in the tailor's aggregate welfare and in the tax-imposing network may be possible. Taxes may prevent the tailor from undertaking investments that in the long run would allow for higher transfers. We think that allowing for such inefficiencies is plausible in the context that we are considering. First, the kin in the village may, in particular, need assistance to cope with short-term shocks. Second, the network may have a different discount rate, as transfers in this context typically go from younger to older cohorts. This is backed-up by anecdotal evidence from fieldwork. However, we impose that $t$ must be such that remittances always ensure that the tailor still has at least a subsistence income, hence:

$$
t<1-\frac{Y^{S u b}}{Y_{1}}
$$

The tax rate, $t$, is known to the tailor.

The sanction, $D$, imposed on the tailor in case of non-compliance with the risk-sharing network is also assumed to depend on the pressure for redistribution, $N$, thus:

$$
D=\gamma(N) \quad \text { with } \gamma<0 \text { and hence } D<0 \text {. }
$$

Hence, the tailor maximises welfare, $W$, over periods 1 and 2 choosing $q$ and the optimal size of $I$ given the credit constraint and the tax that needs to be paid under $q=1$ :

$$
\begin{gathered}
\operatorname{Max}_{\mathrm{q}, \mathrm{I}} W=U\left(C_{1}\right)+\beta E\left[U\left(C_{2}\right)\right]+(1-q) D \\
=U\left(Y_{1}-I-q R\right)+\beta E\left[U\left(Y_{2}-(1-q) \pi S\right)\right]+(1-q) D \\
\text { s.t. Equations (5), (6), (7), (8) and (9). }
\end{gathered}
$$

As illustrated below, optimal choices for capital stocks differ between exiting $(q=0)$ and staying in $(q=1)$ the kinship network. These optimal choices will be denoted ${ }^{*}$ for $q=0$ and ${ }^{* *}$ for $q=1$. The tailor will thus stay in the network if the difference, $\Delta W$, between given optimal choices under each regime is positive.

$$
\Delta W=W(q=1)-W(q=0)
$$




$$
\begin{gathered}
=U\left(Y_{1}^{* *}-I^{* *}-R\right)+\beta U\left(Y_{2}^{* *}\right) \\
-\left(U\left(Y_{1}^{*}-I^{*}\right)+\beta E\left[U\left(Y_{2}^{*}-\pi S\right)\right]+D\right) .
\end{gathered}
$$

We can now also examine the optimal conditions for investment under the two regimes, i.e the growth and insurance regimes. If the tailor opts out of the kinship network $(q=0)$, and hence opts for growth, his decision on capital stocks will follow standard intertemporal decisions rules equating the expected marginal rate of substitution between present and (discounted) future consumption to the marginal rate of transformation between present and future production. Maximising $W$ according to Equation (10) with regard to $I$ then yields:

$$
\frac{1}{\beta}\left(\frac{f\left(K_{1}+I\right)-E(\pi S)}{Y_{1}-I}\right)^{\theta}=f^{\prime}\left(K_{1}+I\right)(\text { growth regime, i.e. } q=0) .
$$

The optimality condition under the insurance regime reads:

$$
\frac{1}{\beta}\left(\frac{f\left(K_{1}+I\right)}{(1-t) Y_{1}-I}\right)^{\theta}=f^{\prime}\left(K_{1}+I\right)(\text { insurance regime, i.e. } q=1) .
$$

This latter condition shows that the tailor's investment decision - if he chooses to stay in the network - is distorted by the tax levied on income from his entrepreneurial activity.

Each of these conditions imply optimal investment amounts, $I^{*}$ and $I^{* *}$, respectively, for a given set of parameters. These optimal amounts in turn can be substituted into Equation (10) and yield the optimal welfare levels, $W^{*}$ and $W^{* *}$, that will be compared by the tailor to decide whether to stay in the network. $I$, and thus $W$, are implicit functions of the various exogenous variables, $\theta, N, S$ and $K$, and Equations (12) and (13) cannot be solved to isolate $I$. However, it is possible to comment on some comparative statics results.

With respect to the choice of $q$, a risk neutral tailor with a given initial capital stock $K_{1}$ would have no preference between the two regimes if the sanction that applies if the tailor leaves the network $(D)$ together with the expected losses due to possible shocks $(S)$ exactly outweigh remittances $(R)$. At this indifference threshold a (more) risk averse tailor will ceteris paribus opt for staying in the kinship network; so will a tailor with a lower initial capital stock and a tailor facing a higher expected loss, $S$. The maximisation problem is more complicated if pressure for redistribution, $N$, varies, as $N$ affects both $R$ and 
$D$. In this case, optimal investment (in the insurance regime) and the choice of staying in the network depend on the exact parametrisation of the model.

In the following we consider the investment decision conditional on having chosen a specific regime. The above conditions show that the tailor's investment decision - if he chooses to stay in the network - is distorted by the tax levied on the income from the entrepreneurial activity. This distortion increases with $N$ : the denominator on the left hand side of Equation (13) will be smaller, the marginal product of capital hence larger, i.e. the capital stock, $K_{2}$, and investment, $I$, smaller, ceteris paribus. The investment decision by the entrepreneur outside the network is not affected by $N$. Under both regimes, investment will be lower the higher the initial capital stock, as a consequence of assuming a neoclassical production function. Similarly, the choice of the utility function implies that investment by more risk averse entrepreneurs will also be lower. Finally, the size and the probability of the shock will negatively affect investment by the tailor who opted out of the network.

Within each regime our problem implies the following signs of the partial derivatives of the optimal amounts of investment $I^{*}$ and $I^{* *}$.

Growth regime $(q=0)$ :

$$
\frac{\partial I^{*}}{\partial N}=0, \frac{\partial I^{*}}{\partial K_{1}}<0, \frac{\partial I^{*}}{\partial \theta}<0, \frac{\partial I^{*}}{\partial(\pi S)}<0 .
$$

Insurance regime $(q=1)$ :

$$
\frac{\partial I^{*}}{\partial N}<0, \frac{\partial I^{*}}{\partial K_{1}}<0, \frac{\partial I^{*}}{\partial \theta}<0, \frac{\partial I^{*}}{\partial(\pi S)}=0 .
$$

From these results we derive the following five hypotheses, which will be tested in our empirical analysis:

- Investment decreases with the initial size of the capital stock.

- Risk-averse tailors tend to choose the insurance regime.

- Redistributive pressure has an ambiguous effect on the regime choice.

- For tailors in the insurance regime, redistributive pressure reduces investment.

- For tailors in the growth regime, redistributive pressure does not affect investment. 


\section{Data}

\subsection{General description of the data}

In January 2011 we interviewed 380 tailors in Ouagadougou with a focus on their kinship networks and questions about their business. The same tailors were re-visited in January 2012 to collect supplementary information. We selected tailors as the target group, as this is a very well defined profession and thus covers a relatively homogeneous group. Most tailors employ some physical capital, most importantly one or more sewing machines; hence investment decisions are an important part of their economic activity.

The questionnaire used was organised around 17 modules covering the following areas: characteristics of the entrepreneur; his firm and his household including questions about his origins and links to that origin; household assets; a module on the structure of the kinship network including transfers sent and received; a module about the start-up phase of the firm; the employed labour force; production; expenditures and fees; savings; physical capital; investment and sources of finance; plans for the future; a module on problems and perspectives; a module on abilities and risk attitudes; the family background; and a module on attitudes toward sharing norms and obligations. The three latter modules were part of the questionnaire in 2012.

The survey was implemented using a two-stage random sampling procedure selecting 400 tailors in 10 out of the 30 sectors of Ouagadougou. The response rate to the survey was $95 \%$. Of the interviewed tailors, 321 reported that they came from a village or another town in Burkina Faso to the capital. Of this group 278 could be re-interviewed in 2012 to collect further information. In our empirical analysis, we focus on these internally migrating entrepreneurs since we are particularly interested in the link that these urban tailors have with their family and kin in their village of origin.

Table 1 shows some key characteristics of these tailors. On average, the tailors remit to about 2.4 persons, either in cash or in kind, mainly to relatives, in particular parents and siblings, and to people in the village of their origin. The average value of these remittances amounts to about 240 Euro ( 1 Euro = 656 CFAF) per year. Most of the remittances are given for food, education and other items including health care. Remittances to co-finance investment other than education are relatively rare. Remittances for ceremonies are frequent, but in terms of their total amount they are rather unimportant. 
When the tailors were asked whether they experienced a shock (up to three could be reported), almost $80 \%$ reported that a shock had occurred in the 12 months preceding the survey, mostly health shocks and other household related shocks. Customers not paying their bills accounted for about $25 \%$ of all reported shocks. These shocks are all idiosyncratic in nature and can in principle be insured through informal insurance networks. When asked about their coping devices (again up to three were asked for), $21 \%$ reported that they received some help from relatives or friends.

With respect to their entrepreneurial activities, the average monthly turnover (derived from their reported sales) amounts to about 225 Euro. The average reported monthly profit is about 20 Euro. Note that this implies that average annual remittances would be as high as average annual profits. Yet, both sales and profits are probably somewhat underestimated. We tried to compute earnings by subtracting all costs for intermediate inputs, taxes, capital, charges and labour from turnover. However, this did not yield plausible numbers. ${ }^{7}$

The sampled tailors report having an average physical capital of about 665 Euro (valued at replacement costs). However, the variance is quite pronounced. Physical capital comprises tools, machines, furniture and the workshop. $76 \%$ of the tailors invested an average amount of 222.50 Euro in the past 12 months, an amount close to remittances. $97 \%$ of all investment items were financed out of own savings. Neither transfers from relatives or friends nor credit are a prominent source of finance. This also holds for start-up investment which is also mainly financed out of savings.

[Table 1 about here]

\subsection{Measures of pressure for redistribution}

To establish causality between the pressure for redistribution and our main outcome of interest - investment - we need to find exogenous measures for redistributive pressure. These measures should not be affected by the tailor's reaction to kinship pressure. Neither observed transfers to the kin nor the number of people seeking (or receiving) transfers are thus appropriate indicators. Instead, we use the number of living siblings, assuming that the pressure for redistribution increases with their number. We have selected this indicator

\footnotetext{
${ }^{7}$ This is in line with De Mel et al.'s (2009) conclusion that simply asking entrepreneurs to report their profits is probably a more accurate measure of profits than detailed questions on revenues and expenses.
} 
for three reasons. First, it is relatively easy to report and measurement error should not be a problem. Second, siblings are, as Table 1 shows, indeed an important recipient of remittances. Third, parents that have many children may themselves have been born into large families. Thus, the number of siblings should be a good proxy for kinship size in general. Obviously, one may argue that siblings per se rather reduce than increase redistributive pressure as the tailor could share the burden of remittances with them. However, this does not seem to be the case. According to the survey respondents, more than half of their siblings are still in the village of origin, most of them do not remit but are among the most often-cited recipients of remittances. ${ }^{8}$

Table 2 presents the descriptive statistics of the indicators used. On average, the sampled tailors have 4.8 siblings who are still alive with a standard deviation of 2.5. $4 \%$ have no living siblings, $57 \%$ have between 4 and 7 living siblings, and $12 \%$ have 8 or more siblings. According to the tailors, 1.8 out of the 4.8 also remit to the family.

[Table 2 about here]

\subsection{Measures of risk aversion}

Given the central role of insurance, risk and risk aversion in our theoretical model, we included a module on risk taking behaviour in the survey. Tailors were asked whether they would conduct the following six actions: (i) drink heavily and ride a motorbike; (ii) use a day's income for gambling; (iii) be in disagreement with an authority on a major issue; (iv) execute an order for a client without asking for an advance; (v) quote far too high a price when negotiating with a new client; and (vi) invest all savings in a new enterprise provided that 'you have a good idea'. Possible answers were 'very likely' (1), 'likely' (2), 'unlikely' (3) and 'very unlikely' (4). Based on the answers to these six actions, we ran a factor analysis and retained the principal factor component as an index of risk aversion. Table 3 shows the answer pattern given by the tailors. While they appear to be quite risk-averse with respect to the first three actions, they are prepared to take some risk with regard to business-related decisions.

\footnotetext{
${ }^{8}$ To test the robustness of our results, we use two additional measures for redistributive pressure - the size of the village of origin and the number of persons visiting the the tailor in the past twelve months. Detailed results of the robustness check can be obtained upon request.
} 
[Table 3 about here]

\subsection{Perceptions about pressure for redistribution}

Before we empirically test the major predictions of our theoretical model, we briefly discuss what the tailors think of sharing obligations when they are directly asked about it. Our survey included a module on norms and obligations in which we asked the tailors to indicate to what extent they agree or disagree with a specific statement. The responses given (see Figure 1 below) provide supportive evidence on the basic intuition presented in this paper, whereby the majority of respondents agree that the pressure for redistribution increases with business success. $27 \%$ perceive it as a distinct obstacle to business development.

[Figure 1 about here]

\section{Empirical specification}

To test the five hypotheses described above, we first estimate simple investment functions and focus on the role played by redistributive pressure and risk aversion. Second, we take our theoretical model literally and investigate the simultaneous decisions of staying in or opting out of the kinship network and of investing.

The investment equation relates the capital investments, $I_{i}$, of entrepreneur $i$ to the pressure for redistribution, $N_{i}$, the capital stock in the previous period, $K L 1_{i}$, and risk aversion, $\theta_{i}$. Since we measure the pressure for redistribution but not the actual level of redistribution, we consider $N_{i}$ to be exogenous. The equation to be estimated reads as follows:

$$
\ln I_{i}=\beta_{0}+\beta_{1} \ln K L 1_{i}+\beta_{2} N_{i}+\beta_{3} \theta_{i}+\beta_{4} \ln H_{i}+X_{i j}^{\prime} \beta_{5 j}+u_{i} .
$$

We include the owner's wealth, $H_{i}$, since wealth is an important source of finance for investment in a context of severe capital market constraints. Wealth includes only household assets, such as ownership of a television, a radio, a bicycle and so on, but no business-related capital goods. As for risk aversion, we used principal component analysis to build an index. The vector $X_{i j}$ stands for a set of $j$ control variables, including age, education and the ethnic affiliation of the entrepreneur, the age of the firm, whether the firm is formal, i.e. formally registered, and whether the entrepreneur is the household head. The vector $X_{i j}$ also includes the number of sisters and brothers outside their household of 
origin, parental education and the father's (former) occupation. These latter controls will reduce any potential unobservable variable bias, i.e. ensure that the number of siblings only captures redistributive pressure and not other family background effects.

We use three different specifications to estimate Equation (14): First, a simple linear regression model; second, a Tobit model, since for about a quarter of all tailors investment in the previous period was zero; and, third, a specification that uses the pressure for redistribution variable, $N_{i}$, as an instrument for reported transfers made.

Based on Equations (12) and (13), we then investigate the simultaneous decisions to stay in (insurance regime) or opt out of (growth regime) the kinship network and to invest. We interpret this simultaneous decision as a problem of sample selection and heterogeneity. This suggests using an endogenous switching regression model (Maddala, 1983) that can jointly estimate the decision about compliance and the decision on how much to invest. We assume that the decision about compliance can be modelled through the following criterion function:

$$
Q^{*}=\gamma_{0}+\gamma_{1} N_{i}+\gamma_{2} \theta_{i}+X_{i j}^{\prime} \gamma_{3 j}+\epsilon_{i}
$$

where $Q^{*}$ describes the latent probability of being in the growth regime (note $Q=(1-q)$ ), i.e. of not complying with the sharing norms and opting out of the kinship network. This probability is modelled as a function of redistributive pressure, risk aversion and other household and family background characteristics (with the variables defined as described above). The tailor opts for the growth regime

$$
Q_{i}=1 \text { if } \gamma_{0}+\gamma_{1} N_{i}+\gamma_{2} \theta_{i}+X_{i j}^{\prime} \gamma_{3 j}+\epsilon_{i}>0
$$

and for the insurance regime

$$
Q_{i}=0 \text { if } \gamma_{0}+\gamma_{1} N_{i}+\gamma_{2} \theta_{i}+X_{i j}^{\prime} \gamma_{3 j}+\epsilon_{i} \leq 0
$$

Obviously, working with this model requires us to determine the status $Q_{i}=1$. We arbitrarily define this status by a threshold at which tailors transfer less than they invest, i.e. $R_{i} / I_{i}<1$. One may argue that the threshold should be set at $R_{i}=0$, but only very few tailors remit nothing at all and hence the chosen operationalisation is more in line with the reality on the ground. ${ }^{9}$

\footnotetext{
${ }^{9}$ The robustness to alternative thresholds is examined below.
} 
Next we define an investment equation for each possible state: compliance (or 'insurance regime', $S$ ) and non-compliance (or 'growth regime', $G$ ).

$$
\begin{aligned}
& \ln I_{i}^{G}=\beta_{0}^{G}+\beta_{1}^{G} \ln K L 1_{i}+\beta_{2}^{G} \ln H_{i}+X_{i j}^{\prime} \beta_{3 j}^{G}+\beta_{4}^{G} N_{i}+\beta_{5}^{G} \theta_{i}+u_{i}^{G} \text { if } Q_{i}=1 \\
& \ln I_{i}^{S}=\beta_{0}^{S}+\beta_{1}^{S} \ln K L 1_{i}+\beta_{2}^{S} \ln H_{i}+X_{i j}^{\prime} \beta_{3 j}^{S}+\beta_{4}^{S} N_{i}+\beta_{5}^{S} \theta_{i}+u_{i}^{S} \text { if } Q_{i}=0 .
\end{aligned}
$$

It is assumed that $\epsilon_{i}, u_{i}^{G}$ and $u_{i}^{S}$ follow a trivariate normal distribution. The covariance between $u_{i}^{G}$ and $u_{i}^{S}$ is not defined as $I_{i}^{G}$ and $I_{i}^{S}$ are never observed simultaneously. The model is identified by construction through non-linearities. Following Lokshin and Sajaia (2004), we estimate this endogenous switching regression model using the full information maximum likelihood (FIML) method. The FIML method estimates the selection equation and the investment equations simultaneously yielding consistent standard errors. For $Q_{i}=1$ we expect $\beta_{4}^{G}$ to be not significantly different from zero.

\section{Test of hypotheses and discussion of results}

\subsection{Redistributive pressure, risk aversion and investment}

Table 4 shows the results for the investment model (Equation (14)). The dependent variable is the $\log$ of the value of total investment in the 12 months preceding the survey. In the first column we show the simple OLS model. In columns (2) and (3) we show the Tobit model and in column (4) we show the model in which the number of siblings is used as an instrument for transfers made.

In column (1) and (2) we see that the number of siblings, here introduced via several categorical variables, our preferred measure of redistributive pressure, is significantly and negatively associated with investment. The marginal effects derived from the Tobit model are a bit lower than in the OLS model (cf. Table A1, appendix) but qualitatively similar. While the coefficient is highest for the dummy for eight or more siblings, the effects of the three dummies are not very precisely estimated and thus not significantly different from each other. In column (3) we alternatively use the continuous number of siblings alive and find a coefficient of -0.16 , implying that for each additional sibling investment declines by about $9 \%$ (cf. Table A1). This is coherent with the marginal effects associated with the estimation in column (2). If we use our measure of redistributive pressure as an instrument for actual transfers made in order to generate variation in the transfers that can be considered exogenous to 
investment, we also find a significant negative effect. In other words, an exogenous increase in transfers made reduces investment. The associated marginal effect is well above unity, implying that the change in investment is larger than the change in transfers. This would suggest that transfers not only reduce the capacity to invest but also reduce the incentive to invest.

With respect to risk-aversion, we also find a strong negative effect (columns (1) to (3)). The computed marginal effects (cf. Table A1), imply that an increase in the risk aversion index by one standard deviation (0.75) reduces investment by about $25 \%$. This is also in line with the hypotheses we had derived from our theoretical model.

Quite interestingly, we also find a robust negative effect associated with belonging to the Mossi ethnic group. As mentioned in the introduction, the Mossi are known for pronounced solidarity with their kin and strong egalitarian norms (Fiske, 1990; Englebert, 1996). According to Fiske (1990) 'in work, transfers and consumption, the Mossi function as a collective "we", not as individuals' (p. 185). On average the Mossi invest about $50 \%$ less than other groups. ${ }^{10}$ The effects of all other control variables (not reported in the table) are also in line with expectations, giving us confidence in the data and formulated model. Overall, the specified model is able to explain quite a lot of the variance in investment, as indicated by an R-squared of about $25 \%$ in the OLS specification.

[Table 4 about here]

We also estimated models with transfers made as dependent variable and the same set of covariates as used above (Tables not shown). Here, in line with our predictions, redistributive pressure comes out with a positive sign, although less precisely estimated than the effects on investment. Risk aversion in turn has a significant positive effect, in fact very similar to the effect above, just of the opposite sign. A one standard deviation increase in risk aversion, raises transfers made by $23 \%$. All this suggests that risk-averse tailors indeed invest less in order to be able to remit more and to get insurance in return. We tested reciprocity by running a probit model of having received help on a variable indicating to how many people the tailor remitted to, provided the tailor has experienced a negative shock. We find that the probability of having

\footnotetext{
${ }^{10}$ However, we did not find significant interaction effects between being Mossi and our measures of redistributive pressure.
} 
received help from others increases significantly with the number of transfers made (Tables not shown).

\subsection{Compliance with sharing norms and investment}

In the following we present the results of the endogenous switching regression model. Table 5 reports two sets of results: first, the results from simultaneously estimating a switching regression model, including a regime choice equation (column (3)) and an investment equation for each regime (column (1) for the growth and column (2) for the insurance regime); and, second, an investment equation for each regime splitting the sample using the threshold defined above (columns (4) and (5)). In columns (1) and (2) we have omitted redistributive pressure and risk aversion from the set of variables. The switching regression shows that redistributive pressure is a significant determinant of the allocation of tailors across the two regimes. Our theoretical model assumes that the effect is ambiguous, as on the one hand, it increases the share of income that has to be remitted; and on the other hand it increases the disutility associated with the sanction in cases where the tailor cuts the ties with his family network. The data suggests that the latter effect indeed dominates: higher pressure reduces the probability of being in the growth regime. This is also coherent with the results of the IV model above, which suggested that kinship size is on average associated with higher, not lower, transfers made and higher transfers were in turn associated with reduced investment. Risk aversion, in line with our hypothesis, also reduces the probability of being in the growth regime.

In both investment equations, the initial capital turns out to be the main determinant of investment. In line with decreasing marginal returns to capital, accumulation will be faster for firms with lower capital stocks. The likelihoodratio test for joint independence of the three equations reported in the last row of Table 5 shows that these three equations are not jointly independent and should hence not be estimated separately. This lends support to the hypothesis that regime choice and investment decisions are indeed taken simultaneously, as postulated by our theoretical model. Figure 2 shows the distribution of the probability to choose the growth regime based on the estimated coefficients in column (3). The plot shows that less than half of the observations have a probability of 0.5 and above. Only few observations are in the upper two deciles.

If we estimate the investment equation for the split sample (columns (4) and 
(5)) and introduce redistributive pressure and risk aversion, we find, again in line with our hypotheses, that the number of siblings reduces investment only for tailors in the insurance regime, but not for those in the growth regime. Even the 'Mossi effect' is only significant for those in the insurance regime. ${ }^{11}$ These results again support the idea that tailors in the growth regime have left their sharing network and are no longer subject to redistributive demands. Because they have left, kinship characteristics no longer affect investment. This result is robust to reasonable variations in the growth-insurance-regime threshold. For tailors in the growth regime, the effects identified also hold when alternative measures for the pressure to redistribute are used, such as village size or the number of visitors in the twelve months preceding the survey.

[Table 5 and Figure 2 about here]

\subsection{Transfers and investment across the capital distribution}

As a descriptive robustness check to the above results, we now examine whether some tailors (in the growth regime) invest and end up with higher capital stocks and relatively low remittances, while others (in the insurance regime) remit, do not invest and stay with low capital stocks. Put differently, we have to exclude that those in the insurance regime are not just those tailors who have already achieved their optimal capital stock and thus can 'afford' to show solidarity with their kin.

Figure 3a shows mean annual investment and transfers made across the capital distribution. We can see that both absolute investment and transfers increase with the size of the capital stock. Up to the seventh decile annual transfers exceed annual investment. Above the seventh decile however, investment takes off and in the tenth decile is almost twice as large as transfers.

In Figure 3b we look at investment and transfers as a share of annual profits. Whereas the transfer ratio declines with increasing capital, although with some fluctuations, the investment ratio goes up. The slope is particularly steep between the fifth and eighth decile. Only in the upper two deciles does the curve flatten out. This happens at a very high level, where virtually all profits are re-invested. At the lower end of the capital distribution we find exactly the opposite. Almost $90 \%$ of the total profits are remitted and only a meagre $12 \%$

\footnotetext{
${ }^{11}$ In principle the Mossi variable belongs to the regime choice equation, however the maximisation problem did not converge in this case, hence we had to remove the 'Mossi' variable and just put it in the investment equation.
} 
are re-invested. These results further support the hypothesis that there are two distinct behavioural patterns.

[Figure 3 about here]

\section{Conclusion}

For a long time, the anthropological literature has suggested that sharing norms may imply adverse incentive effects which hamper investment in productive activities. However, the empirical evidence for such effects is still scarce. Existing studies on the topic have often addressed the issue of forced solidarity in isolation, neglecting the interplay with risk, which may also pose a major constraint to entrepreneurs.

In this paper, we develop a theoretical model on the interplay between solidarity and investment, where the entrepreneur faces a trade-off between complying with sharing norms and business expansion. Opting for an insurance regime, the entrepreneur makes transfers to his kin, gets insurance, but forgoes future earnings because of lower investment. Following a growth regime, the entrepreneurs breaks with the norms, steps out of the kinship network, bears a social sanction and is no longer insured, but does not have to remit and can realize his desired investment plans. The regime choice, i.e. the decision to comply with the norms or not, is driven by the level of risk aversion desired by the entrepreneur, the pressure for redistribution and the return on the investment.

We test the main predictions of our model with data from a representative sample of tailors in Ouagadougou. The empirical analysis confirms the main predictions of the model and we can identify two distinct groups of tailors who operate under an insurance or a growth regime. Specifically, the joint estimation of the regime choice and the investment decision yields results that are consistent with a world, in which some entrepreneurs step out of sharing networks. As predicted by our theoretical model, for tailors in the insurance regime investment declines strongly with the pressure for redistribution. This is not the case for tailors in the growth regime whose investment decision is not affected by kinship pressure.

In this paper we do not deny the positive aspects of family and kinship ties, often referred to as social capital. On the contrary, we are well aware of their importance in contexts where market mechanisms are non-existent or fail. Our aim is to highlight the possible trade-off faced by tailors due to the 
coexistence of modern economic activities and traditional norms and institutions. Although we do not explicitly address the issue of efficiency, it is likely that the distortive effects of kinship pressure on investment decisions imply opportunities for pareto-improvements, i.e. both the kinship network and the entrepreneur could be better off if the entrepreneur could realise his investment plans and make lump-sum payments to compensate his social network. Prevailing sharing norms and the associated insurance schemes may not (yet) have adapted to the presence of modern economic activities and the related growth processes that rely on savings and investment. In a context of such norms and institutions, providing insurance to entrepreneurs and their kin might be an effective means of spurring investment in small and micro enterprises. Such a policy would be more effective the more sharing networks are motivated by insurance and not by pure egalitarian norms. Obviously the introduction of insurance, possibly along with credit, does create its own problems in a setting where institutional capacity and trust in formal institutions is weak. However, a number of countries in Sub-Saharan Africa have started to introduce (or at least to experiment with) health insurance schemes. Given that health shocks, as shown, pose an important threat on households, health insurance schemes may imply a softening of sharing obligations.

More generally, existing policies targeted at entrepreneurs often have a mono-causal foundation. This is, for instance, the case for micro-credit programmes that address credit market imperfections but ignore other bottlenecks that may constrain entrepreneurial activities. Our analysis, however, clearly indicates that the issues of savings and credit constraints, risk, and social norms and preferences are closely interrelated. Future work on micro and small enterprise performance and policy interventions towards these firms should not neglect these interdependencies.

\section{Appendix}

[Table A1 about here]

\section{References}

Abel, A. and Eberly, J. (1994). 'A Unified Model of Investment Under Uncertainty', American Economic Review, vol. 84, pp. 1369-84. 
Alger, I. and Weibull, J.W. (2008). 'Family Ties, Incentives and Development. A Model of Coerced Altruism', in (K. Basu and R. Kanbur, eds.), Arguments for a Better World: Essays in Honor of Amartya Sen, Vol. 2, pp. 178-201, Oxford: Oxford University Press.

Alger, I. and Weibull, J.W. (2010). 'Kinship, Incentives, and Evolution', American Economic Review, vol. 100, pp. 1725-58.

Baar, A.M. (2002). 'The functional diversity and spillover effects of social capital', Journal of African Economies, vol. 11(1), pp. 90-113.

Baland, J.-M., Guirkinger, C. and Mali, C. (2011). 'Pretending to be Poor: Borrowing to Escape Forced Solidarity in Cameroon', Economic Development and Cultural Change, vol. 60, pp. 1-16.

Barth, F. (1967). 'On the Study of Social Change', American Anthropologist (new series), vol. 69(6), pp. 661-9.

Bauer, P.T. and Yamey, B.S. (1957). The Economics of Under-Developed Countries, Cambridge: Cambridge University Press.

Brune, L., Gine, X., Goldberg, J. and Yang, D. (2011). 'Commitments to Save. A Field Experiment in Rural Malawi', Policy Research Working Paper 5748, The World Bank.

Cameron, A.C. and Triverdi, P.K. (2005). Microeconometrics: Methods and Applications, Cambridge: Cambridge University Press.

De Mel, S., McKenzie, D.J. and Woodruff, C. (2008). 'Returns to Capital in Microenterprises: Evidence from a Field Experiment', Quarterly Journal of Economics, vol. 123(4), pp. 1329-72.

De Mel, S., McKenzie, D.J. and Woodruff, C. (2009). 'Measuring microenterprise profits: Must we ask how the sausage is made', Journal of Development Economics, vol. 88, pp. 19-31.

Di Falco, S. and Bulte, E. (2011). 'The Dark Side of Social Capital: Kinship, Consumption, and Savings', Journal of Development Studies, vol. 47(8), pp. $1128-54$.

Duflo, E., Kremer, M. and Robinson, J. (2011). 'Nudging Farmers to use Fertilizer: Evidence from Kenya.' American Economic Review, vol. 101(6), pp. 2350-90. 
Englebert, P. (1996). Burkina Faso: Unsteady Statehood in West-Africa, Boulder: Westview.

Fafchamps, M. (2002). 'Returns to social network capital among traders', Oxford Economic Papers, vol. 54(2), pp. 173-206.

Fafchamps, M. and Pender, J. (1997). 'Precautionary Saving, Credit Constraints, and Irreversible Investment: Theory and Evidence from SemiArid India', Journal of Business and Economic Statistics, vol. 15(2), pp. 180-94.

Fafchamps, M., McKenzie, D.J., Quinn, S. and Woodruff, C. (2011). 'When is capital enough to get female microenterprises growing? Evidence from a randomized experiment in Ghana', DP8466, Centre for Economic Policy Research.

Fiske, A.P. (1990). 'Relativity within Mosse ("Mossi") Culture: Four Incommensurable Models for Social Relationship', Ethos, vol. 18(2), pp. 180-204.

Granovetter, M. (1973). 'The strength of weak ties', American Journal of Sociology, vol. 78 , pp. 1360-80.

Granovetter, M. (1983). 'The strength of weak ties: a network theory revisited', Sociological Theory, vol. 1, pp. 201-33.

Granovetter, M. (1985). 'Economic action and social structure: the problem of embeddedness', American Journal of Sociology, vol. 91(3), pp. 481-510.

Grimm, M., Krüger, J. and Lay, J. (2011). 'Barriers to entry and returns to capital in informal activities: Evidence from Sub-Saharan Africa', Review of Income and Wealth, vol. 57, pp. S27-53.

Hadnes, M., Vollan, B. and Kosfeld, M. (2011). 'The Dark Side of Solidarity: An Experimental Approach to the Impact of Solidarity on Work Output', Mimeo, University of Frankfurt.

Hirschman, A.O. (1958). The Strategy of Economic Development, New Haven and London: Yale University Press.

Hoff, K. and Sen, A. (2006). 'The Kin as a Poverty Trap', in (S. Bowles, S.N. Durlauf and K. Hoff, eds.), Poverty Traps, pp. 95-115, New York: Princeton University Press. 
Jakiela, P. and Ozier, O. (2012). 'Does Africa Need a Rotten Kin Theorem. Experimental evidence from village economies', Policy Research Working Paper 6085, The World Bank.

Kremer, M., Lee, J.N. and Robinson, J.M. (2010). 'The Return to Capital for Small Retailers in Kenya: Evidence from Inventories', Mimeo, Harvard University.

La Ferrara, E. (2007). 'Family and Kinship ties in Development: An Economist's Perspective', Paper presented at the 5th AFD-EUDN Conference, Paris, December.

Lewis, W.A. (1955). The Theory of Economic Growth, Homewood, Illinois: Richard D. Irwin.

Lokshin, M. and Sajaia, Z. (2004). 'Maximum-likelihood estimation of endogenous switching regression models', Mimeo, The World Bank.

Maddala, G. (1983). Limited-Dependent and Qualitative Variables in Econometrics. Econometric Society Monographs No. 3, New York: Cambridge University Press.

McKenzie, D.J. and Woodruff, C. (2006). 'Do Entry Costs Provide an Empirical Basis for Poverty Traps? Evidence from Mexican Microenterprises.' Economic Development and Cultural Change, vol. 55 (1), pp. 3-42.

McKenzie, D.J. and Woodruff, C. (2008). 'Experimental Evidence on Returns to Capital and Access to Finance in Mexico', World Bank Economic Review, vol. 22(3), pp. 457-82.

Meier, G.M. and Baldwin, R.E. (1957). Economic Development: Theory, History, Policy, New York: John Wiley and Sons.

Platteau, J.-P. (2000). Institutions, Social Norms and Economic Development, Amsterdam: Harwood Academic Publishers.

Rostow, W.W. (1960). The Stages of Economic Growth: A Non-Communist Manifesto, Cambridge: Cambridge University Press. 


\section{Tables and figures}

Table 1: Descriptive statistics ( $\mathrm{N}=278)$

Mean S.D.

\begin{tabular}{|c|c|c|}
\hline \multicolumn{3}{|l|}{ Owner characteristics } \\
\hline Male (=1) & 0.81 & \\
\hline Age & 34.8 & 9.3 \\
\hline Household head (=1) & 0.75 & \\
\hline Primary school completed (=1) & 0.33 & \\
\hline Mossi (=1) & 0.75 & \\
\hline Muslim (=1) & 0.55 & \\
\hline \multicolumn{3}{|l|}{ Number of persons remitted to (past 12 months) } \\
\hline Siblings & 0.9 & 1.1 \\
\hline Any direct family member & 1.9 & 1.3 \\
\hline Any person from village (incl. family in that village) & 1.2 & 1.4 \\
\hline Any person (i.e. all persons remitted to) & 2.4 & 1.4 \\
\hline \multicolumn{3}{|l|}{ Amounts remitted in Euro (past 12 months) } \\
\hline Siblings & 77.7 & 257.9 \\
\hline Any direct family member & 163.2 & 330.2 \\
\hline Any person from village (incl. family in that village) & 79.5 & 132.7 \\
\hline Any person (i.e. all persons remitted to) & 237.9 & 909.5 \\
\hline \multicolumn{3}{|l|}{ Share of total remittances given for } \\
\hline Food & 0.48 & 0.40 \\
\hline Education & 0.15 & 0.21 \\
\hline Investment & 0.06 & 0.21 \\
\hline Drugs & 0.03 & 0.13 \\
\hline Ceremonies & 0.02 & 0.11 \\
\hline Other (incl. health care other than drugs) & 0.26 & 0.33 \\
\hline Tailor reported shock that occurred to him/her $(=1)$ & 0.79 & \\
\hline \multicolumn{3}{|l|}{ Type of problem for three most important shocks (shares) } \\
\hline Medical problem with high financial costs & 0.29 & \\
\hline Death of a household member & 0.12 & \\
\hline Wedding, baptism, other ceremony & 0.13 & \\
\hline Customer didn't pay & 0.24 & \\
\hline Other & 0.21 & \\
\hline Households receiving help following a shock $(=1)$ & 0.21 & \\
\hline
\end{tabular}

Table continues next page. 
Table 1: (... continued $)$

\begin{tabular}{|c|c|c|}
\hline & Mean & S.D. \\
\hline \multicolumn{3}{|l|}{ Firm characteristics } \\
\hline Age of firm & 7.4 & 6.7 \\
\hline Firm is registered $(=1)$ & 0.31 & \\
\hline Has a workshop $(=1)$ & 0.84 & \\
\hline Has access to electricity $(=1)$ & 0.85 & \\
\hline Has electric sewing machine $(=1)$ & 0.68 & \\
\hline Monthly turnover in Euro & 225.3 & 645.5 \\
\hline Physical capital in Euro & 664.2 & 1320.8 \\
\hline Firms size (staff, incl. owner and fam. helpers) & 3.8 & 1.8 \\
\hline Total monthly hours & 868.9 & 457.4 \\
\hline Invested past 12 months $(=1)$ & 0.76 & \\
\hline If invested, financed through savings $(=1)$ & 0.97 & \\
\hline Investment past 12 months in Euro & 222.5 & 432.9 \\
\hline Current owner set up the enterprise $(=1)$ & 96.8 & \\
\hline \multicolumn{3}{|c|}{ For those, most important source of finance (shares) } \\
\hline Savings & 0.86 & \\
\hline Donation & 0.11 & \\
\hline Heritage & 0 & \\
\hline Family loan & 0.02 & \\
\hline Other & 0.01 & \\
\hline \multicolumn{3}{|l|}{... second most important source of finance (shares) } \\
\hline Savings & 0.04 & \\
\hline Donation & 0.28 & \\
\hline Heritage & 0.01 & \\
\hline Family loan & 0.03 & \\
\hline Other & 0.64 & \\
\hline Help from others, those still paying back $(=1)$ & 0.11 & \\
\hline
\end{tabular}

Source: Own data, collected in January 2011 and 2012 in Ouagadougou, Burkina Faso. 
Table 2: Measures of the pressure for redistribution $(\mathrm{N}=278)$

\begin{tabular}{lcc}
\hline & Mean & S.D. \\
\hline Number of siblings alive (shares of tailors) & & \\
No siblings & 0.04 \\
1 to 3 & 0.27 \\
4 to 7 & 0.57 \\
8 and more & 0.12 & \\
Average no. of siblings alive & 4.77 & 2.50 \\
Average no. of siblings remitting to your family in the village of origin & 1.77 & 2.36 \\
\hline
\end{tabular}

Source: Own data, collected in January 2011 and 2012 in Ouagadougou, Burkina Faso.

Table 3: Descriptive statistics of variables that enter risk aversion index $(\mathrm{N}=278)$

\begin{tabular}{lcccc}
\hline Action & Very likely & Likely & Unlikely & Very unlikely \\
\hline Drinking heavily and driving a motorbike & 0.01 & 0.00 & 0.04 & 0.95 \\
Using the daily income for gambling & 0.01 & 0.03 & 0.11 & 0.85 \\
Being in disagreement with an authority & 0.13 & 0.17 & 0.13 & 0.57 \\
Exec. an order without asking any advance & 0.52 & 0.22 & 0.12 & 0.14 \\
Asking a far too high price while negot. with new client & 0.35 & 0.15 & 0.15 & 0.27 \\
Investing all your savings in a new enterprise & 0.21 & 0.36 \\
\hline
\end{tabular}

Source: Own data, collected in January 2011 and 2012 in Ouagadougou, Burkina Faso. 
Table 4: The effect of redistributive pressure and risk aversion on investment

\begin{tabular}{|c|c|c|c|c|}
\hline & $(1)$ & $(2)$ & (3) & (4) \\
\hline & OLS & Tobit & Tobit & IV-Tobit \\
\hline Ln capital stock in $\mathrm{t}-1$ & $-0.366 * * *$ & $-0.465^{* * *}$ & $-0.463 * * *$ & $-0.322 * *$ \\
\hline & $(0.048)$ & $(0.060)$ & $(0.060)$ & $(0.138)$ \\
\hline No siblings alive & Ref. & Ref. & & \\
\hline 1 to 3 siblings alive & -0.551 & -0.850 & & \\
\hline & $(0.647)$ & $(0.717)$ & & \\
\hline 4 to 7 siblings alive & $-1.297 * *$ & $-1.763^{* *}$ & & \\
\hline & $(0.635)$ & $(0.699)$ & & \\
\hline 8 and more siblings alive & $-1.492 * *$ & $-1.936 * *$ & & \\
\hline & $(0.723)$ & $(0.823)$ & & \\
\hline Number of siblings alive & & & $-0.159 * *$ & \\
\hline & & & $(0.068)$ & \\
\hline Ln amount remitted to village & & & & $-1.627^{*}$ \\
\hline (instrumented) & & & & $(0.907)$ \\
\hline Risk aversion index & $-0.498^{* * *}$ & $-0.622 * * *$ & $-0.651 * * *$ & -0.003 \\
\hline & $(0.169)$ & $(0.200)$ & $(0.205)$ & $(0.516)$ \\
\hline $\operatorname{Mossi}(=1)$ & $-0.749 * *$ & $-0.968^{* * *}$ & $-1.008^{* * *}$ & -0.946 \\
\hline & $(0.300)$ & $(0.368)$ & $(0.374)$ & $(0.646)$ \\
\hline Controls & Yes & Yes & Yes & Yes \\
\hline Constant & $7.472^{* * *}$ & $8.455^{* * *}$ & $7.628^{* * *}$ & $7.849 * * *$ \\
\hline & $(0.975)$ & $(1.130)$ & $(0.944)$ & $(1.770)$ \\
\hline R-squared & 0.250 & & & \\
\hline $\mathrm{N}$ & 278 & 278 & 278 & 278 \\
\hline Censored N & & 67 & 67 & \\
\hline $\begin{array}{l}\text { Note: Robust standard errors in } \\
\text { Asset index, age of firm (years), } \\
\text { completed }(=1) \text {, no. of brothers } \\
\text { father primary completed }(=1) \text {, } \\
\text { independent non-agricultural we }\end{array}$ & $\begin{array}{l}\text { s. }{ }^{*} \mathrm{p}<0.10 \\
\text { mal }(=1), \mathrm{a} \\
\text { e househol } \\
\text { mary comp }\end{array}$ & $\begin{array}{l}{ }^{*} \mathrm{p}<0.05, * \\
\text { of tailor (ye } \\
\text { f origin, no } \\
\text { ed }(=1) \text {, fat }\end{array}$ & $\begin{array}{l}\mathrm{p}<0.01 \text {. Co } \\
\text { ), tailor is } \mathrm{h} \\
\mathrm{f} \text { sisters ou } \\
\text { is } / \text { was a } \mathrm{f}\end{array}$ & $\begin{array}{l}\text { ol variables i } \\
\text { sehold head } \\
\text { e the househ } \\
\text { er }(=1) \text {, fath }\end{array}$ \\
\hline Source: Own data, collected in Ja & & & & \\
\hline
\end{tabular}


Table 5: Mixture model - Growth vs. insurance regime

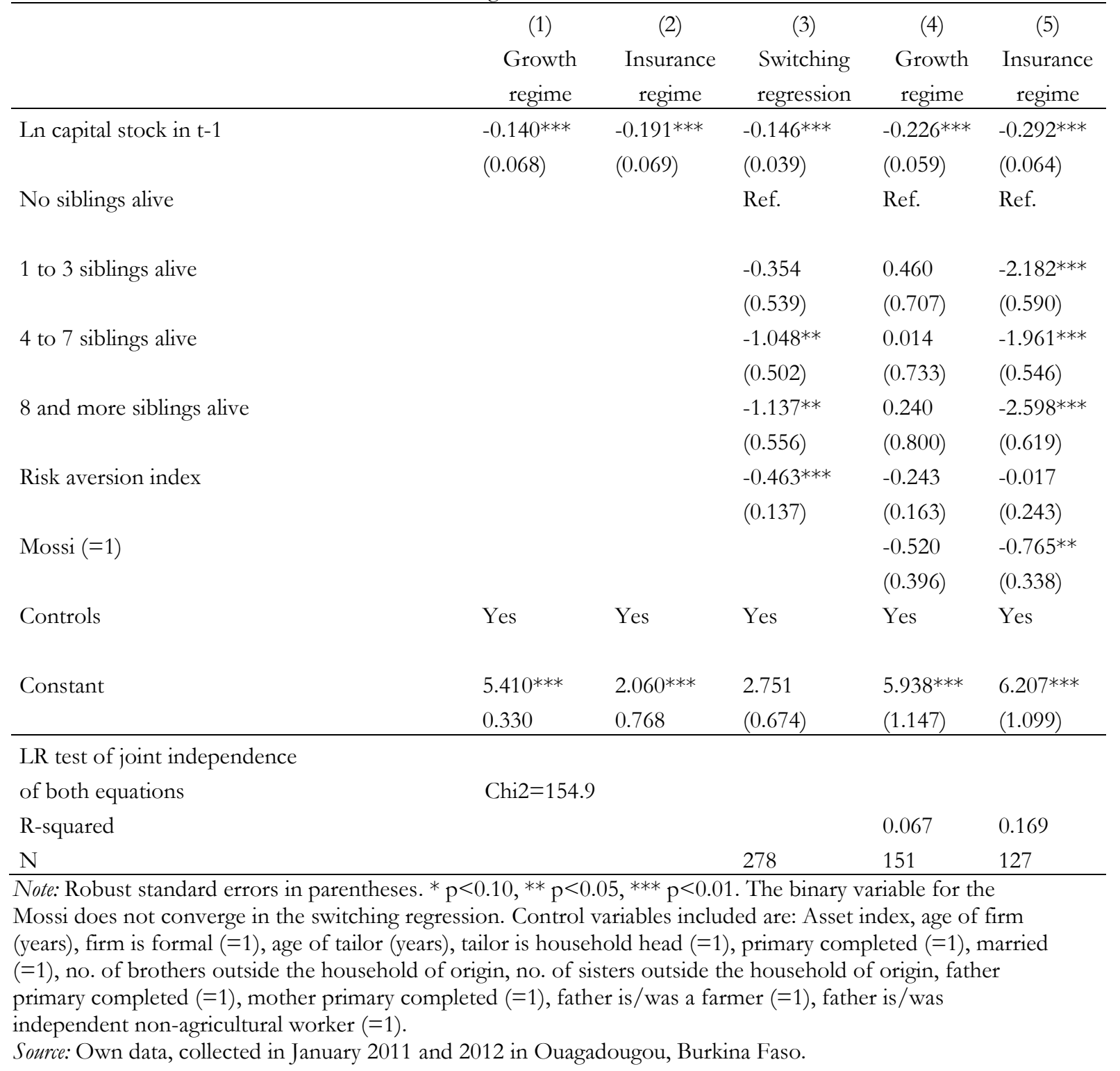


Figure 1: Perceptions about pressure for redistribution (share of respondents)

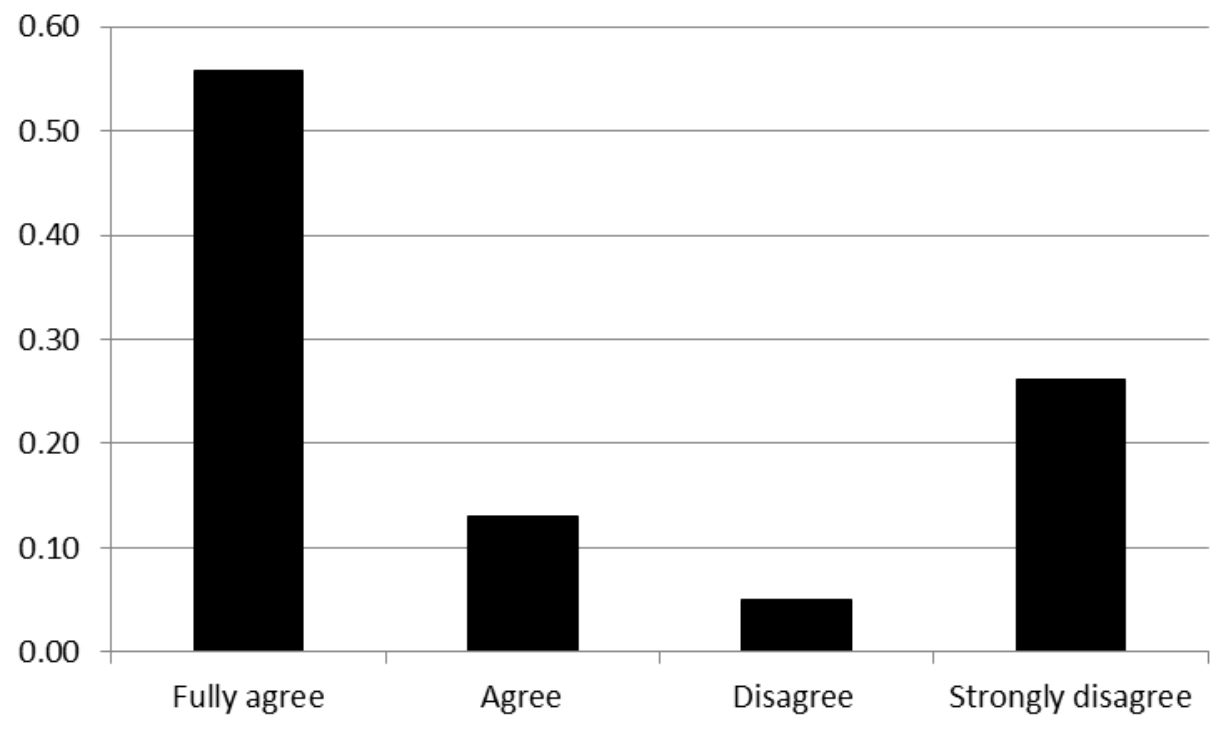

1a: "Every time I have money, my spouse or other family members in or outside the household ask for a part of it"

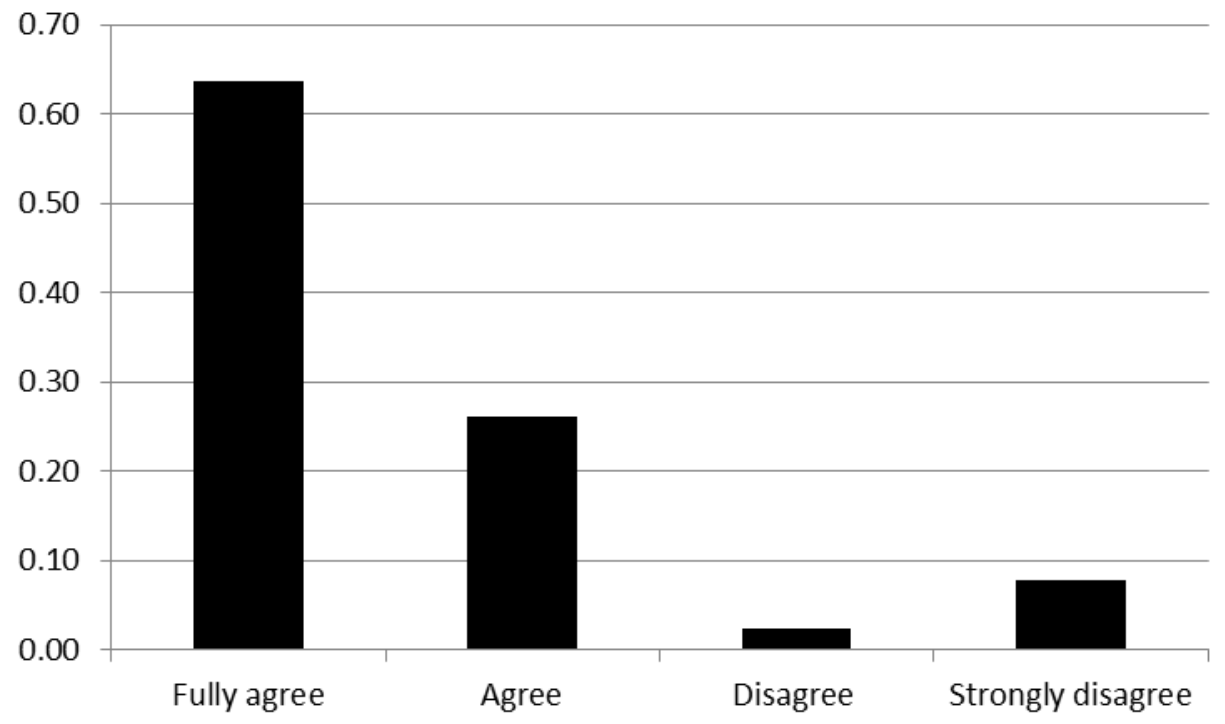

1b: "Someone who succeeds with his/her firm will get additional requests from the family and friends to help financially" 


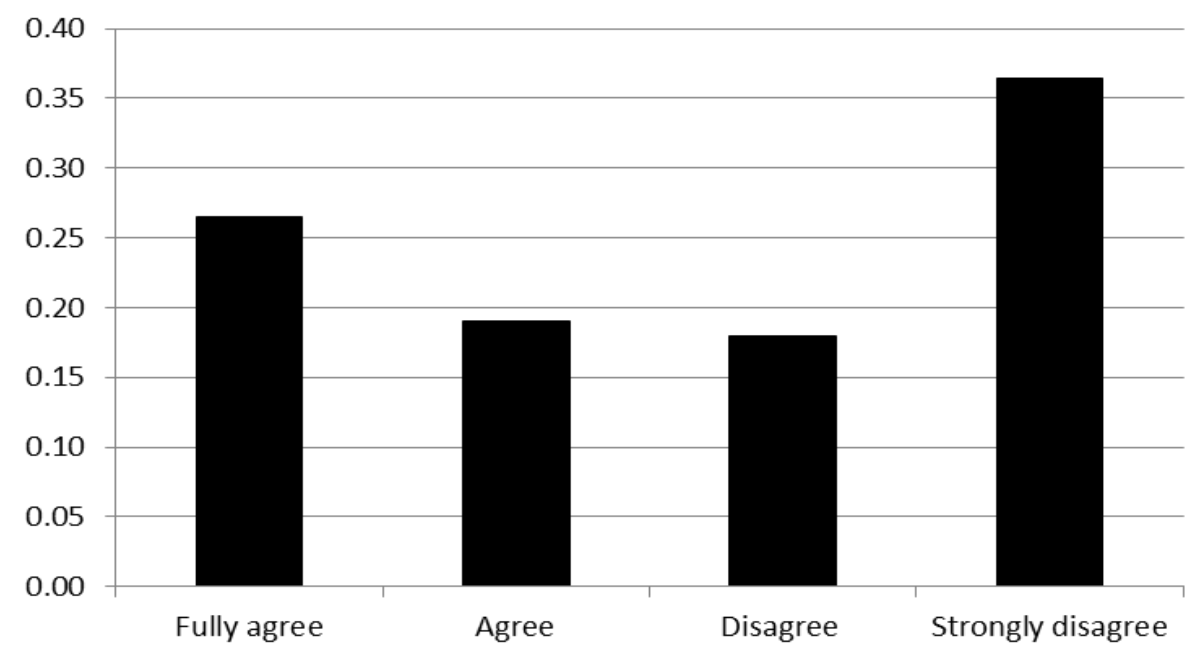

1c: "Requests from the family or friends can be so constraining that it is better not to develop the business"

Figure 2: Distribution of the probability to choose the growth regime, predictions based on switching regression in Table 5 (kernel density estimate)

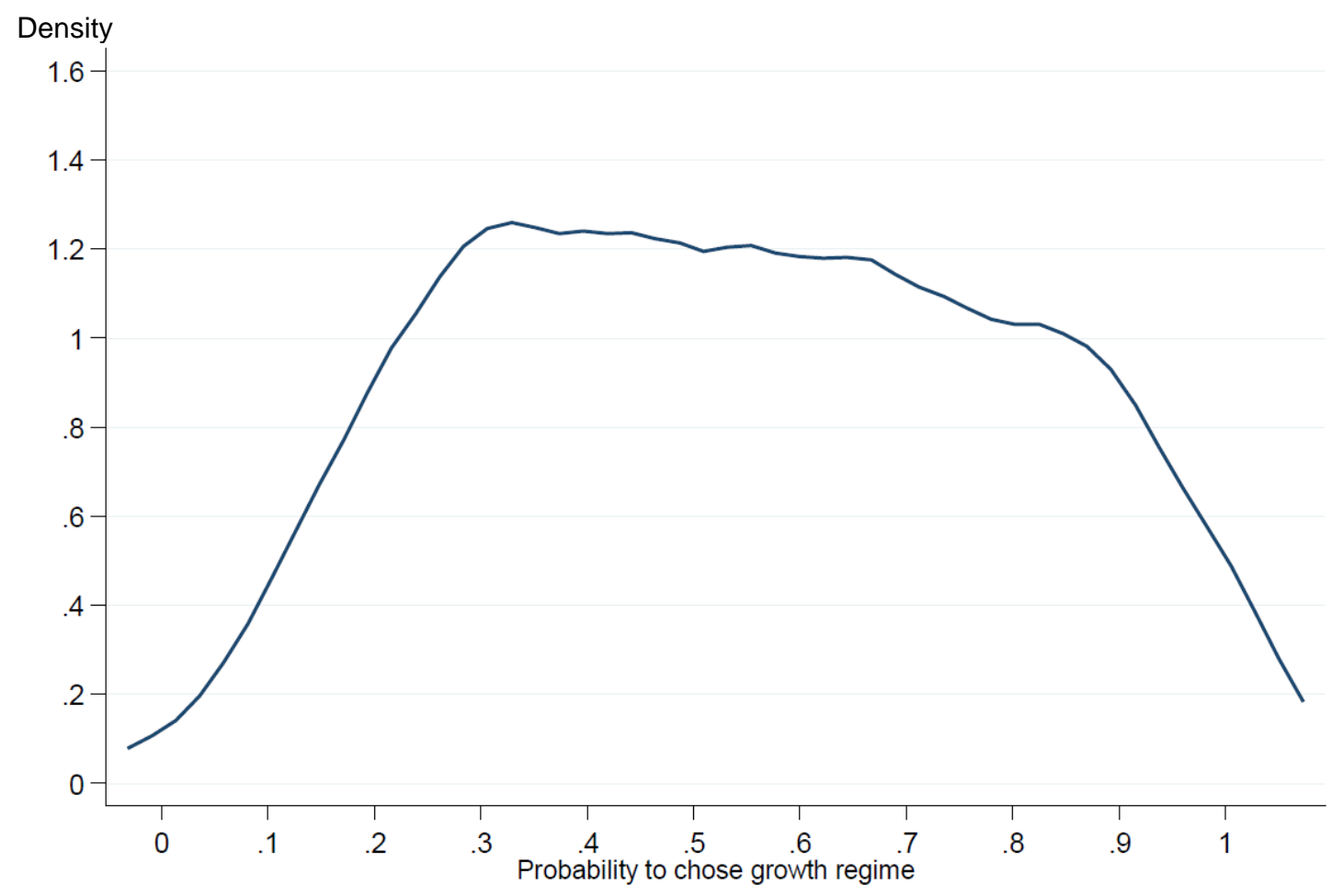


Figure 3: Investment and remittances across the capital distribution

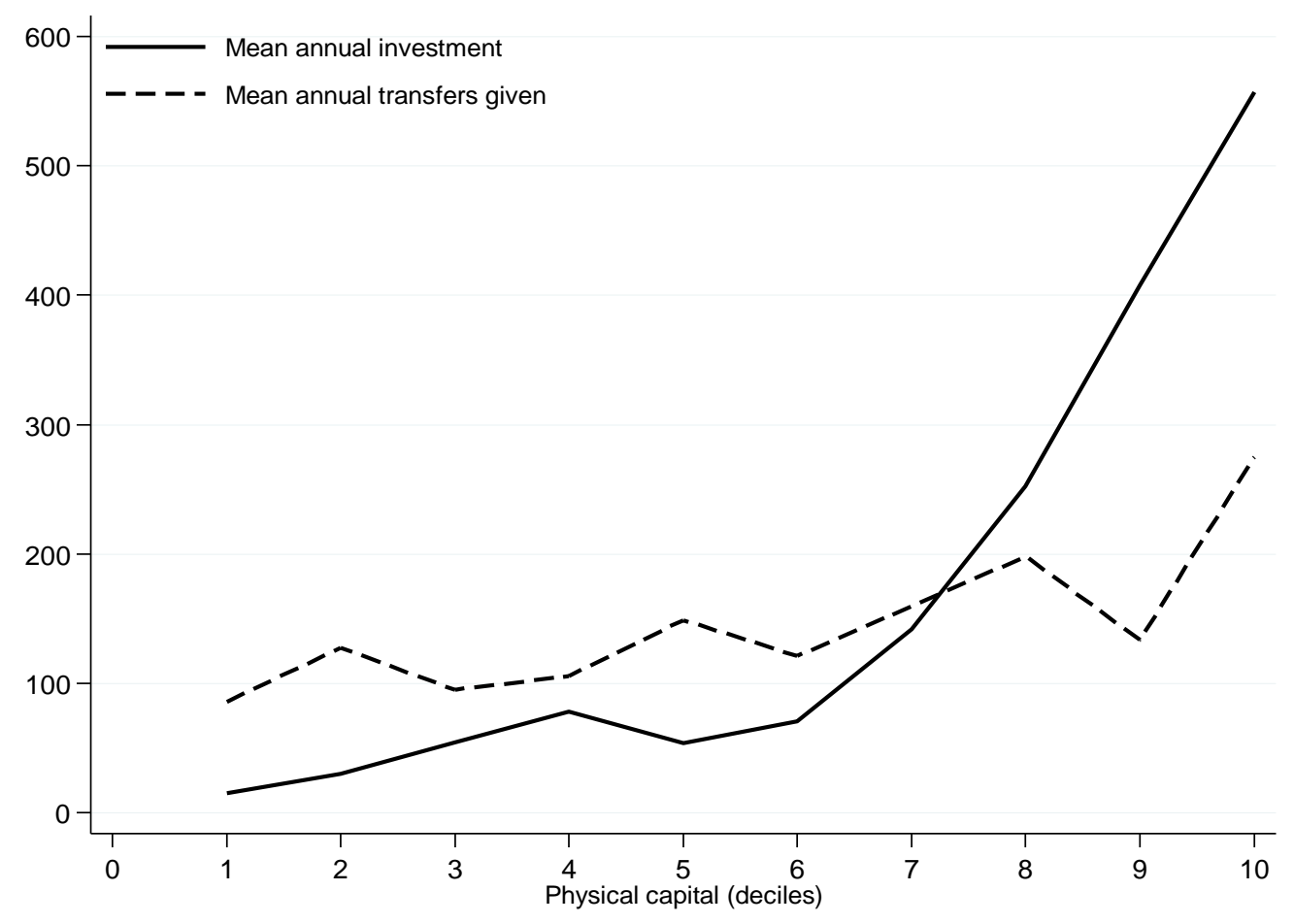

3a: Mean annual investment and remittances

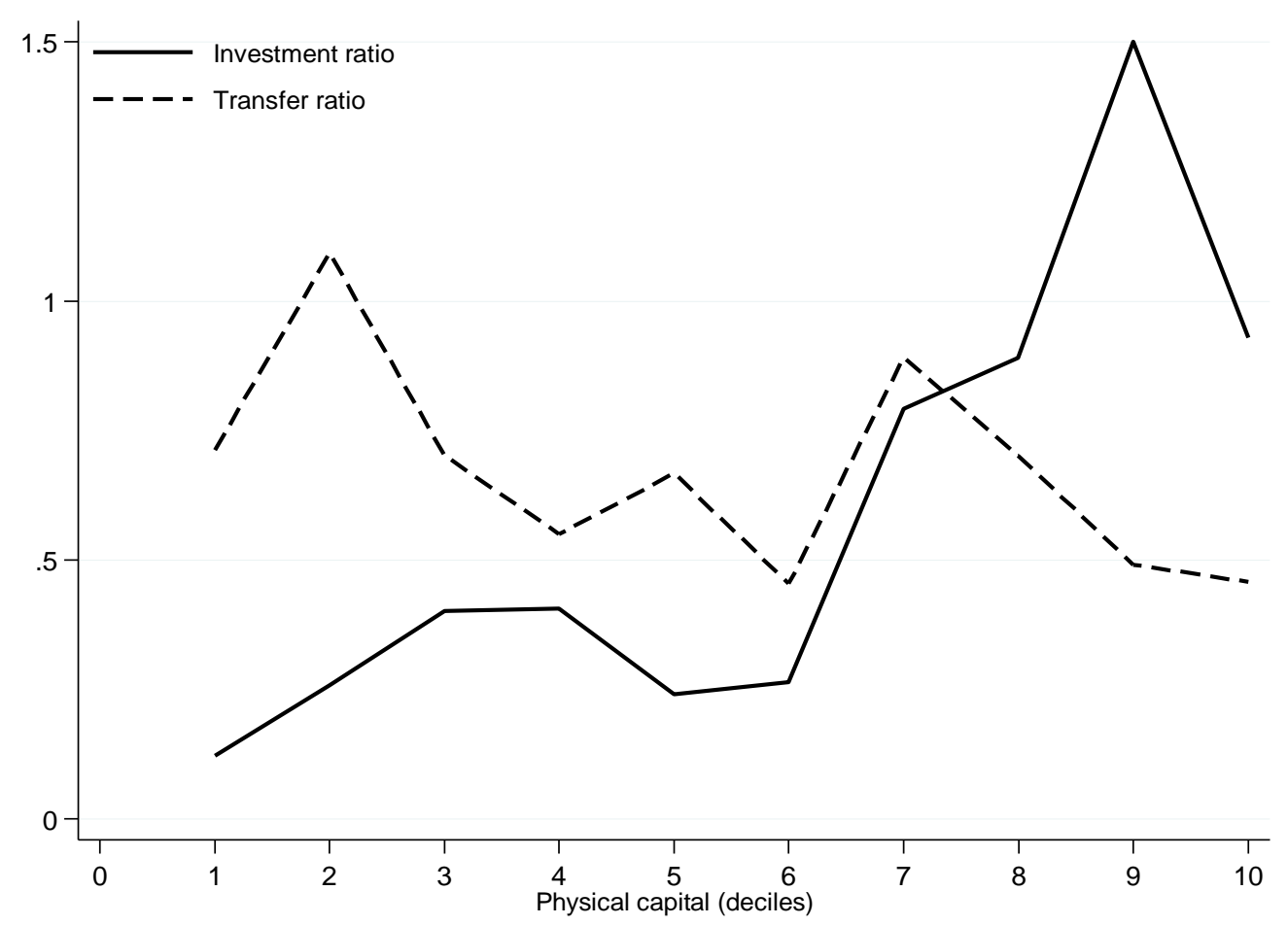

3b: Mean investment and transfers given as a share of annual profits 
Table A1: Marginal effects (ME) computed at sample means on uncensored observations (cf. Table 4)

\begin{tabular}{lcc}
\hline & \multicolumn{2}{c}{$\begin{array}{c}\text { Column number in Table } 4 \\
\text { to which ME refer to }\end{array}$} \\
\hline Ln capital stock in t-1 & $(2)$ & $(3)$ \\
1 to 3 siblings alive & -0.252 & -0.251 \\
4 to 7 siblings alive & -0.461 & \\
8 and more siblings alive & -0.957 & \\
Number of siblings alive & -1.051 & \\
Risk aversion index & & -0.086 \\
Mossi (=1) & -0.338 & -0.352 \\
Source: Own data, collected in January 2011 and 2012 in Ouagadougou, Burkina Faso.
\end{tabular}




\section{Supplemental material}

Table S1: Measures of the pressure for redistribution $(\mathrm{N}=278)$ (cf. Table 2, expanded)

Mean

S.D.

\begin{tabular}{|c|c|c|}
\hline \multicolumn{3}{|l|}{ Number of siblings alive (shares of tailors) } \\
\hline No siblings & 0.04 & \\
\hline 1 to 3 & 0.27 & \\
\hline 4 to 7 & 0.57 & \\
\hline 8 and more & 0.12 & \\
\hline Average no. of siblings alive & 4.77 & 2.50 \\
\hline Average no. of siblings remitting to your family in the village of origin & 1.77 & 2.36 \\
\hline \multicolumn{3}{|l|}{ Village size (shares of tailors) } \\
\hline Less than 1,000 & 0.20 & \\
\hline 1,000 to 10,000 & 0.32 & \\
\hline More than 10,000 & 0.48 & \\
\hline \multicolumn{3}{|l|}{ Number of visitors from village (last year, shares of tailors) } \\
\hline no visitors & 0.17 & \\
\hline 1 to 4 & 0.38 & \\
\hline 5 to 9 & 0.24 & \\
\hline 10 to 19 & 0.13 & \\
\hline 20 and more & 0.08 & \\
\hline
\end{tabular}

Source: Own data, collected in January 2011 and 2012 in Ouagadougou, Burkina Faso. 
Table S2: The effect of redistributive pressure and risk aversion on investment (cf. Table 4, expanded)

\begin{tabular}{|c|c|c|c|c|c|c|}
\hline & $\begin{array}{c}(1) \\
\text { OLS }\end{array}$ & $\begin{array}{c}(2) \\
\text { Tobit }\end{array}$ & $\begin{array}{c}(3) \\
\text { Tobit }\end{array}$ & $\begin{array}{c}(4) \\
\text { Tobit }\end{array}$ & $\begin{array}{c}(5) \\
\text { Tobit }\end{array}$ & $\begin{array}{c}(6) \\
\text { IV-Tobit }\end{array}$ \\
\hline \multirow[t]{2}{*}{ Ln capital stock in $\mathrm{t}-1$} & $-0.366^{* * *}$ & $-0.465^{* * *}$ & $-0.463 * * *$ & $-0.467 * * *$ & $-0.447 * * *$ & $-0.322^{* *}$ \\
\hline & $(0.048)$ & $(0.060)$ & $(0.060)$ & $(0.060)$ & $(0.059)$ & $(0.138)$ \\
\hline \multirow[t]{2}{*}{ Asset index } & 0.126 & 0.029 & 0.035 & 0.019 & -0.002 & -0.016 \\
\hline & $(0.174)$ & $(0.242)$ & $(0.251)$ & $(0.252)$ & $(0.252)$ & $(0.394)$ \\
\hline \multirow[t]{2}{*}{ Age of firm (years) } & $-0.062^{* * *}$ & $-0.077 * * *$ & $-0.082^{* * *}$ & $-0.079 * * *$ & $-0.084 * * *$ & -0.061 \\
\hline & $(0.023)$ & $(0.029)$ & $(0.029)$ & $(0.030)$ & $(0.029)$ & $(0.053)$ \\
\hline \multirow[t]{2}{*}{ Firm is formal $(=1)$} & $0.584^{*}$ & $0.699 *$ & $0.766^{* *}$ & $0.842^{* *}$ & $0.648^{*}$ & -0.173 \\
\hline & $(0.305)$ & $(0.384)$ & $(0.376)$ & $(0.374)$ & $(0.372)$ & $(0.773)$ \\
\hline No siblings alive & Ref. & Ref. & & & & \\
\hline \multirow[t]{2}{*}{1 to 3 siblings alive } & -0.551 & -0.850 & & & & \\
\hline & $(0.647)$ & $(0.717)$ & & & & \\
\hline \multirow[t]{2}{*}{4 to 7 siblings alive } & $-1.297 * *$ & $-1.763^{* *}$ & & & & \\
\hline & $(0.635)$ & $(0.699)$ & & & & \\
\hline \multirow[t]{2}{*}{8 and more siblings alive } & $-1.492 * *$ & $-1.936 * *$ & & & & \\
\hline & $(0.723)$ & $(0.823)$ & & & & \\
\hline \multirow[t]{2}{*}{ Number of siblings alive } & & & $-0.159 * *$ & $-0.154 * *$ & & \\
\hline & & & $(0.068)$ & $(0.068)$ & & \\
\hline Village size $<1,000$ & & & Ref. & Ref. & & \\
\hline \multirow[t]{2}{*}{$1,000<$ village size $<10,000$} & & & & -0.150 & & \\
\hline & & & & $(0.421)$ & & \\
\hline \multirow[t]{2}{*}{ Village size $>10,000$} & & & & -0.444 & & \\
\hline & & & & $(0.391)$ & & \\
\hline \multirow[t]{2}{*}{20 visitors and more last year } & & & & -0.414 & & \\
\hline & & & & $(0.573)$ & & \\
\hline Ln amount remitted to village & & & & & -0.084 & $-1.627^{*}$ \\
\hline (instrumented in col. (6)) & & & & & $(0.072)$ & $(0.907)$ \\
\hline \multirow[t]{2}{*}{ Risk aversion index } & $-0.498^{* * *}$ & $-0.622^{* * *}$ & $-0.651 * * *$ & $-0.640 * * *$ & $-0.633^{* * *}$ & -0.003 \\
\hline & $(0.169)$ & $(0.200)$ & $(0.205)$ & $(0.208)$ & $(0.208)$ & $(0.516)$ \\
\hline \multirow[t]{2}{*}{ Age of tailor (years) } & $-0.036 * *$ & $-0.042^{* *}$ & -0.035 & -0.033 & -0.022 & -0.008 \\
\hline & $(0.017)$ & $(0.021)$ & $(0.021)$ & $(0.021)$ & $(0.021)$ & $(0.039)$ \\
\hline \multirow[t]{2}{*}{ Tailor is household head $(=1)$} & -0.271 & -0.416 & -0.462 & -0.517 & -0.468 & 0.764 \\
\hline & $(0.289)$ & $(0.340)$ & $(0.338)$ & $(0.337)$ & $(0.346)$ & $(0.987)$ \\
\hline \multirow[t]{2}{*}{ Primary completed (=1) } & $0.716^{* *}$ & $0.706^{* *}$ & $0.692 *$ & $0.846^{* *}$ & 0.552 & 0.570 \\
\hline & $(0.283)$ & $(0.359)$ & $(0.364)$ & $(0.380)$ & $(0.361)$ & $(0.590)$ \\
\hline
\end{tabular}

Table continues next page. 
Table S2: (... continued)

\begin{tabular}{|c|c|c|c|c|c|c|}
\hline & $\begin{array}{c}(1) \\
\text { OLS }\end{array}$ & $\begin{array}{c}(2) \\
\text { Tobit }\end{array}$ & $\begin{array}{c}(3) \\
\text { Tobit }\end{array}$ & $\begin{array}{c}(4) \\
\text { Tobit }\end{array}$ & $\begin{array}{c}(5) \\
\text { Tobit }\end{array}$ & $\begin{array}{c}(6) \\
\text { IV-Tobit }\end{array}$ \\
\hline \multirow[t]{2}{*}{ Mossi (=1) } & $-0.749 * *$ & $-0.968^{* * *}$ & $-1.008^{* * *}$ & $-1.002^{* * *}$ & $-1.018^{* * *}$ & -0.946 \\
\hline & $(0.300)$ & $(0.368)$ & $(0.374)$ & $(0.380)$ & $(0.370)$ & $(0.646)$ \\
\hline \multirow[t]{2}{*}{ No. of brothers outside $\mathrm{HH}$ of origin } & -0.056 & -0.092 & -0.103 & -0.081 & -0.106 & 0.023 \\
\hline & $(0.053)$ & $(0.074)$ & $(0.073)$ & $(0.074)$ & $(0.072)$ & $(0.140)$ \\
\hline \multirow[t]{2}{*}{ No. of sisters outside $\mathrm{HH}$ of origin } & $0.100 *$ & $0.128^{*}$ & $0.126^{*}$ & $0.133^{*}$ & 0.105 & 0.027 \\
\hline & $(0.057)$ & $(0.074)$ & $(0.076)$ & $(0.077)$ & $(0.076)$ & $(0.127)$ \\
\hline \multirow[t]{2}{*}{ Father primary completed $(=1)$} & 0.724 & 0.805 & 0.862 & 0.930 & 0.910 & 0.071 \\
\hline & $(0.577)$ & $(0.699)$ & $(0.727)$ & $(0.715)$ & $(0.728)$ & $(1.276)$ \\
\hline \multirow[t]{2}{*}{ Mother primary completed $(=1)$} & $-1.182^{*}$ & $-1.480^{* *}$ & $-1.458^{*}$ & $-1.472 *$ & $-1.338^{*}$ & -0.551 \\
\hline & $(0.626)$ & $(0.748)$ & $(0.766)$ & $(0.755)$ & $(0.764)$ & $(1.650)$ \\
\hline \multirow[t]{2}{*}{ Father is/was farmer $(=1)$} & $0.624^{*}$ & $0.802^{*}$ & $0.759 *$ & $0.788^{*}$ & $0.798^{*}$ & 1.045 \\
\hline & $(0.320)$ & $(0.414)$ & $(0.416)$ & $(0.415)$ & $(0.420)$ & $(0.703)$ \\
\hline \multirow[t]{2}{*}{ Father is/was indep. non-agric. $(=1)$} & 0.268 & 0.393 & 0.284 & 0.292 & 0.332 & 0.670 \\
\hline & $(0.327)$ & $(0.407)$ & $(0.392)$ & $(0.399)$ & $(0.392)$ & $(0.707)$ \\
\hline \multirow[t]{2}{*}{ Constant } & $7.472 * * *$ & $8.455^{* * *}$ & $7.628 * * *$ & $7.685^{* * *}$ & $6.667 * * *$ & $7.849 * * *$ \\
\hline & $(0.975)$ & $(1.130)$ & $(0.944)$ & $(0.960)$ & $(0.856)$ & $(1.770)$ \\
\hline \multirow[t]{2}{*}{ / sigma } & & $2.456^{* * *}$ & $2.484 * * *$ & $2.464 * * *$ & $2.501 * * *$ & \\
\hline & & $(0.124)$ & $(0.124)$ & $(0.124)$ & $(0.124)$ & \\
\hline R-squared & 0.250 & & & & & \\
\hline $\mathrm{N}$ & 278 & 278 & 278 & 278 & 278 & 278 \\
\hline Censored N & & 67 & 67 & 67 & 67 & \\
\hline
\end{tabular}

Note: Robust standard errors in parentheses. ${ }^{*} \mathrm{p}<0.10,{ }^{* *} \mathrm{p}<0.05,{ }^{* * *} \mathrm{p}<0.01$.

Source: Own data, collected in January 2011 and 2012 in Ouagadougou, Burkina Faso. 
Table S2.1: Marginal effects computed at sample means on uncensored observations (cf. Table S2)

Column number in Table S2 to which ME refer to

\begin{tabular}{lllll} 
& \multicolumn{1}{r}{$(2)$} & $(3)$ & $(4)$ & $(5)$ \\
\hline Ln capital stock in t-1 & -0.252 & -0.251 & -0.252 & -0.243 \\
Asset index & 0.016 & 0.019 & 0.010 & -0.001 \\
Age of firm (years) & -0.042 & -0.044 & -0.043 & -0.046 \\
Firm is formal (=1) & 0.379 & 0.415 & 0.455 & 0.352 \\
1 to 3 siblings alive & -0.461 & & & \\
4 to 7 siblings alive & -0.957 & & & \\
8 and more siblings alive & -1.051 & & & \\
Number of siblings alive & & -0.086 & -0.083 & \\
Village size < 1,000 & & & & \\
1,000 < village size <10,000 & & & -0.081 & \\
Village size > 10,000 & & & -0.240 & \\
20 visitors and more last year & & & -0.224 & \\
Ln amount remitted to village & & & & -0.046 \\
Risk aversion index & -0.338 & -0.352 & -0.346 & -0.344 \\
Age of tailor (years) & -0.023 & -0.019 & -0.018 & -0.012 \\
Tailor is household head (=1) & -0.226 & -0.250 & -0.280 & -0.254 \\
Primary completed (=1) & 0.383 & 0.375 & 0.457 & 0.300 \\
Mossi (=1) & -0.525 & -0.546 & -0.542 & -0.552 \\
No of brothers outside HH of origin & -0.050 & -0.056 & -0.044 & -0.058 \\
No of sisters outside HH of origin & 0.070 & 0.068 & 0.072 & 0.057 \\
Father primary completed (=1) & 0.437 & 0.466 & 0.503 & 0.494 \\
Mother primary completed (=1) & -0.803 & -0.789 & -0.795 & -0.726 \\
Father is/was farmer (=1) & 0.436 & 0.411 & 0.426 & 0.433 \\
Father is/was indep. non-agric. (=1) & 0.213 & 0.154 & 0.158 & 0.180 \\
\hline
\end{tabular}


Table S3: The effect of redistributive pressure and risk aversion on remittances

\begin{tabular}{|c|c|c|c|c|c|}
\hline & $\begin{array}{c}(1) \\
\text { OLS }\end{array}$ & $\begin{array}{c}(2) \\
\text { Tobit }\end{array}$ & $\begin{array}{c}(3) \\
\text { Tobit }\end{array}$ & $\begin{array}{c}(4) \\
\text { Tobit }\end{array}$ & $\begin{array}{c}(5) \\
\text { NbReg }\end{array}$ \\
\hline No siblings alive & Ref. & Ref. & & & Ref. \\
\hline 1 to 3 siblings alive & $\begin{array}{l}0.806 \\
(0.632)\end{array}$ & $\begin{array}{l}2.320 \\
(1.686)\end{array}$ & & & $\begin{array}{l}0.796 \\
(0.527)\end{array}$ \\
\hline 4 to 7 siblings alive & $\begin{array}{l}1.219 * * \\
(0.609)\end{array}$ & $\begin{array}{l}3.038^{*} \\
(1.657)\end{array}$ & & & $\begin{array}{l}1.066^{* *} \\
(0.526)\end{array}$ \\
\hline 8 and more siblings alive & $\begin{array}{l}1.438^{*} \\
(0.730)\end{array}$ & $\begin{array}{l}3.461 * \\
(1.818)\end{array}$ & & & $\begin{array}{l}1.242^{* *} \\
(0.555)\end{array}$ \\
\hline Number of siblings alive & & & $\begin{array}{l}0.141 \\
(0.120)\end{array}$ & $\begin{array}{l}0.161 \\
(0.122)\end{array}$ & \\
\hline Village size $<1,000$ & & & & Ref. & \\
\hline $1,000<$ village size $<10,000$ & & & & $\begin{array}{l}1.216 \\
(0.748)\end{array}$ & \\
\hline Village size $>10,000$ & & & & $\begin{array}{l}1.383^{*} \\
(0.741)\end{array}$ & \\
\hline 20 visitors and more last year & & & & $\begin{array}{l}0.836 \\
(1.005)\end{array}$ & \\
\hline Risk aversion index & $\begin{array}{c}0.385^{*} \\
(0.214)\end{array}$ & $\begin{array}{c}0.823^{*} \\
(0.453)\end{array}$ & $\begin{array}{c}0.883^{*} \\
(0.453)\end{array}$ & $\begin{array}{c}0.803^{*} \\
(0.445)\end{array}$ & $\begin{array}{l}0.249 * * \\
(0.120)\end{array}$ \\
\hline Age of tailor (years) & $\begin{array}{l}0.024 \\
(0.016)\end{array}$ & $\begin{array}{l}0.052^{*} \\
(0.030)\end{array}$ & $\begin{array}{l}0.043 \\
(0.030)\end{array}$ & $\begin{array}{l}0.048 \\
(0.030)\end{array}$ & $\begin{array}{l}0.020 * * \\
(0.009)\end{array}$ \\
\hline Tailor is household head $(=1)$ & $\begin{array}{l}0.736 * * \\
(0.348)\end{array}$ & $\begin{array}{l}1.504 * * \\
(0.730)\end{array}$ & $\begin{array}{l}1.659 * * \\
(0.726)\end{array}$ & $\begin{array}{l}1.613 * * \\
(0.719)\end{array}$ & $\begin{array}{l}0.613^{* * *} \\
(0.219)\end{array}$ \\
\hline Primary completed $(=1)$ & $\begin{array}{l}-0.049 \\
(0.320)\end{array}$ & $\begin{array}{l}-0.090 \\
(0.605)\end{array}$ & $\begin{array}{l}-0.077 \\
(0.613)\end{array}$ & $\begin{array}{l}-0.406 \\
(0.636)\end{array}$ & $\begin{array}{l}0.029 \\
(0.163)\end{array}$ \\
\hline $\operatorname{Mossi}(=1)$ & $\begin{array}{l}-0.053 \\
(0.345)\end{array}$ & $\begin{array}{l}0.106 \\
(0.643)\end{array}$ & $\begin{array}{l}0.175 \\
(0.647)\end{array}$ & $\begin{array}{l}0.075 \\
(0.642)\end{array}$ & $\begin{array}{l}-0.000 \\
(0.176)\end{array}$ \\
\hline No. of brothers outside $\mathrm{HH}$ of origin & $\begin{array}{l}0.075 \\
(0.071)\end{array}$ & $\begin{array}{l}0.134 \\
(0.126)\end{array}$ & $\begin{array}{l}0.140 \\
(0.125)\end{array}$ & $\begin{array}{l}0.117 \\
(0.126)\end{array}$ & $\begin{array}{l}0.027 \\
(0.029)\end{array}$ \\
\hline No. of sisters outside $\mathrm{HH}$ of origin & $\begin{array}{r}-0.050 \\
(0.063)\end{array}$ & $\begin{array}{l}-0.115 \\
(0.127)\end{array}$ & $\begin{array}{l}-0.113 \\
(0.126)\end{array}$ & $\begin{array}{l}-0.126 \\
(0.127)\end{array}$ & $\begin{array}{l}-0.010 \\
(0.033)\end{array}$ \\
\hline Father primary completed $(=1)$ & $\begin{array}{l}-0.410 \\
(0.595)\end{array}$ & $\begin{array}{l}-1.040 \\
(1.254)\end{array}$ & $\begin{array}{l}-1.079 \\
(1.226)\end{array}$ & $\begin{array}{l}-1.011 \\
(1.258)\end{array}$ & $\begin{array}{l}-0.167 \\
(0.311)\end{array}$ \\
\hline Mother primary completed $(=1)$ & $\begin{array}{l}0.475 \\
(0.767)\end{array}$ & $\begin{array}{l}0.869 \\
(1.567)\end{array}$ & $\begin{array}{l}0.918 \\
(1.574)\end{array}$ & $\begin{array}{l}0.928 \\
(1.578)\end{array}$ & $\begin{array}{l}0.339 \\
(0.429)\end{array}$ \\
\hline Father is/was farmer $(=1)$ & $\begin{array}{l}0.268 \\
(0.363)\end{array}$ & $\begin{array}{l}0.438 \\
(0.668)\end{array}$ & $\begin{array}{l}0.349 \\
(0.662)\end{array}$ & $\begin{array}{l}0.490 \\
(0.665)\end{array}$ & $\begin{array}{l}0.027 \\
(0.172)\end{array}$ \\
\hline Father is/was indep. non-agric. $(=1)$ & $\begin{array}{l}0.058 \\
(0.362)\end{array}$ & $\begin{array}{l}-0.020 \\
(0.693)\end{array}$ & $\begin{array}{l}0.006 \\
(0.687)\end{array}$ & $\begin{array}{l}0.095 \\
(0.693)\end{array}$ & $\begin{array}{l}-0.139 \\
(0.186)\end{array}$ \\
\hline
\end{tabular}

Table continues next page. 
Table S3: (... continued)

\begin{tabular}{|c|c|c|c|c|c|}
\hline & (1) & (2) & (3) & (4) & (5) \\
\hline & OLS & Tobit & Tobit & Tobit & NbReg \\
\hline \multirow[t]{2}{*}{ Constant } & -0.352 & $-5.341 * *$ & $-3.043^{*}$ & $-4.166 * *$ & $-2.200 * * *$ \\
\hline & $(0.965)$ & $(2.318)$ & (1.684) & $(1.832)$ & $(0.684)$ \\
\hline \multirow[t]{2}{*}{ / sigma } & & $4.040^{* * *}$ & $4.038^{* * *}$ & $4.012^{* * *}$ & \\
\hline & & $(0.206)$ & $(0.206)$ & $(0.208)$ & \\
\hline R-squared & 0.027 & & & & \\
\hline $\mathrm{N}$ & 278 & 278 & 278 & 278 & 278 \\
\hline
\end{tabular}

Note: Robust standard errors in parentheses. ${ }^{*} \mathrm{p}<0.10,{ }^{* *} \mathrm{p}<0.05,{ }^{* * *} \mathrm{p}<0.01$.

Source: Own data, collected in January 2011 and 2012 in Ouagadougou, Burkina Faso.

Table S3.1: Marginal effects computed at sample means on uncensored observations (cf. Table S3)

Column number in Table S3 to which ME refer to

(2)

(3)

(4)

\begin{tabular}{llll}
\hline 1 to 3 siblings alive & 0.852 & & \\
4 to 7 siblings alive & 1.116 & & \\
8 and more siblings alive & 1.271 & & 0.059 \\
Number of siblings alive & & 0.052 & \\
Village size $<1,000$ & & & 0.448 \\
$1,000<$ Village size $<10,000$ & & & 0.509 \\
Village size $>10,000$ & & & 0.308 \\
20 visitors and more last year & & & 0.296 \\
Risk aversion index & 0.302 & 0.326 & 0.018 \\
Age of tailor (years) & 0.019 & 0.016 & 0.594 \\
Tailor is household head (=1) & 0.552 & 0.613 & -0.149 \\
Primary completed $(=1)$ & -0.033 & -0.028 & 0.028 \\
Mossi $(=1)$ & 0.039 & 0.065 & 0.043 \\
No. of brothers outside HH of origin & 0.049 & 0.052 & -0.046 \\
No. of sisters outside HH of origin & -0.042 & -0.042 & -0.372 \\
Father primary completed (=1) & -0.382 & -0.399 & 0.342 \\
Mother primary completed (=1) & 0.319 & 0.339 & 0.181 \\
Father is/ was farmer $(=1)$ & 0.161 & 0.129 & 0.035 \\
Father is/was indep. non-agric. $(=1)$ & -0.007 & 0.002 & \\
\hline
\end{tabular}


Table S4: The effect of remittances on obtained support in times of shocks

\begin{tabular}{|c|c|c|c|c|}
\hline & (1) & $(2)$ & (3) & (4) \\
\hline & Probit & Heck-Probit & Heck-Probit & Probit \\
\hline \multirow[t]{2}{*}{ No. of persons remitted (village) } & $0.144 * *$ & $0.107 * *$ & & \\
\hline & $(0.067)$ & $(0.052)$ & & \\
\hline \multirow[t]{2}{*}{ No. of persons remitted (all) } & & & $0.130^{* *}$ & $0.106^{*}$ \\
\hline & & & $(0.062)$ & $(0.057)$ \\
\hline \multirow[t]{2}{*}{ Ln capital stock in $\mathrm{t}-1$} & -0.029 & -0.024 & -0.025 & -0.023 \\
\hline & $(0.038)$ & $(0.031)$ & $(0.038)$ & $(0.034)$ \\
\hline \multirow[t]{2}{*}{ Asset index } & 0.118 & 0.081 & 0.120 & 0.104 \\
\hline & $(0.118)$ & $(0.097)$ & $(0.120)$ & $(0.113)$ \\
\hline \multirow[t]{2}{*}{ Age of firm (years) } & -0.017 & -0.008 & -0.018 & -0.011 \\
\hline & $(0.018)$ & $(0.009)$ & $(0.019)$ & $(0.012)$ \\
\hline \multirow[t]{2}{*}{ Firm is formal $(=1)$} & -0.190 & -0.179 & -0.168 & -0.160 \\
\hline & $(0.206)$ & $(0.150)$ & $(0.204)$ & $(0.183)$ \\
\hline \multirow[t]{2}{*}{ Risk aversion index } & -0.062 & & -0.030 & \\
\hline & $(0.130)$ & & $(0.128)$ & \\
\hline \multirow[t]{2}{*}{ Age of tailor (years) } & 0.010 & & 0.013 & \\
\hline & $(0.014)$ & & $(0.014)$ & \\
\hline \multirow[t]{2}{*}{ Tailor is household head (=1) } & -0.173 & & -0.180 & \\
\hline & $(0.226)$ & & $(0.232)$ & \\
\hline \multirow[t]{2}{*}{ Primary completed $(=1)$} & 0.159 & & 0.111 & \\
\hline & $(0.198)$ & & $(0.200)$ & \\
\hline \multirow[t]{2}{*}{ Mossi (=1) } & 0.283 & 0.240 & 0.308 & 0.269 \\
\hline & $(0.221)$ & $(0.163)$ & $(0.216)$ & $(0.193)$ \\
\hline \multirow[t]{2}{*}{ No. of brothers outside $\mathrm{HH}$ of origin } & 0.033 & 0.017 & 0.029 & 0.023 \\
\hline & $(0.041)$ & $(0.035)$ & $(0.041)$ & $(0.037)$ \\
\hline \multirow[t]{2}{*}{ No. of sisters outside $\mathrm{HH}$ of origin } & -0.036 & -0.031 & -0.034 & -0.032 \\
\hline & $(0.037)$ & $(0.031)$ & $(0.037)$ & $(0.037)$ \\
\hline \multirow[t]{2}{*}{ Father primary completed $(=1)$} & 0.367 & 0.257 & 0.331 & 0.276 \\
\hline & $(0.361)$ & $(0.221)$ & $(0.369)$ & $(0.340)$ \\
\hline \multirow[t]{2}{*}{ Mother primary completed $(=1)$} & $1.033^{* *}$ & $0.972 * *$ & $1.003^{*}$ & $0.939 *$ \\
\hline & $(0.498)$ & $(0.410)$ & $(0.514)$ & $(0.479)$ \\
\hline \multirow[t]{2}{*}{ Father is/was farmer $(=1)$} & 0.326 & 0.286 & 0.270 & 0.235 \\
\hline & $(0.227)$ & $(0.175)$ & $(0.221)$ & $(0.202)$ \\
\hline \multirow[t]{2}{*}{ Father is/was indep. non-agric. $(=1)$} & $0.411^{*}$ & $0.359 * *$ & 0.329 & 0.311 \\
\hline & $(0.221)$ & $(0.175)$ & $(0.218)$ & $(0.210)$ \\
\hline \multirow[t]{2}{*}{ Constant } & $-1.188^{* *}$ & $-0.594 * *$ & $-1.365^{* *}$ & $-0.743^{* *}$ \\
\hline & $(0.594)$ & $(0.276)$ & $(0.618)$ & $(0.378)$ \\
\hline \multirow[t]{2}{*}{ athrho } & & -12.562 & & -1.059 \\
\hline & & $(4325.723)$ & & $(1.146)$ \\
\hline $\mathrm{N}$ & 242 & 278 & 242 & 278 \\
\hline
\end{tabular}

Note: Robust standard errors in parentheses. ${ }^{*} \mathrm{p}<0.10,{ }^{* *} \mathrm{p}<0.05,{ }^{* * *} \mathrm{p}<0.01$.

Source: Own data, collected in January 2011 and 2012 in Ouagadougou, Burkina Faso. 
Table S4.1: Marginal effects (ME) computed at sample means (cf. Table S4)

$$
\text { Column number in }
$$

Table 4 to

which ME refer to

(1)

(3)

No. of persons remitted (village)

0.049

No. of persons remitted (all)

0.044

Ln capital stock in $\mathrm{t}-1$

$-0.010-0.008$

Asset index

Age of firm (years)

$0.040 \quad 0.041$

Firm is formal $(=1)$

$-0.006 \quad-0.006$

Risk aversion index

$-0.063 \quad-0.056$

Age of tailor (years)

$-0.021-0.010$

$0.003 \quad 0.004$

Tailor is household head $(=1)$

$-0.060 \quad-0.063$

Primary completed $(=1)$

$0.055 \quad 0.038$

Mossi (=1)

$0.092 \quad 0.100$

No. of brothers outside $\mathrm{HH}$ of origin

$0.011 \quad 0.010$

No. of sisters outside $\mathrm{HH}$ of origin

$-0.012-0.011$

Father primary completed $(=1)$

$0.133 \quad 0.119$

Mother primary completed $(=1)$

$0.392 \quad 0.381$

Father is/was farmer (=1)

$0.115 \quad 0.094$

Father is/was indep. non-agric. (=1)

$0.144 \quad 0.115$


Table S5: Mixture model - Growth vs. insurance regime (cf. Table 5, expanded)

\begin{tabular}{|c|c|c|c|c|c|}
\hline & $\begin{array}{l}\text { (1) } \\
\text { Growth } \\
\text { regime }\end{array}$ & $\begin{array}{c}\quad(2) \\
\text { Insurance } \\
\text { regime }\end{array}$ & $\begin{array}{l}\quad(3) \\
\text { Switching } \\
\text { regression }\end{array}$ & $\begin{array}{c}(4) \\
\text { Growth } \\
\text { regime }\end{array}$ & $\begin{array}{c}\quad(5) \\
\text { Insurance } \\
\text { regime }\end{array}$ \\
\hline Ln capital stock in $\mathrm{t}-1$ & $\begin{array}{l}-0.140^{* * *} \\
(0.068)\end{array}$ & $\begin{array}{l}-0.191 * * * \\
(0.069)\end{array}$ & $\begin{array}{l}-0.146^{* * *} \\
(0.039)\end{array}$ & $\begin{array}{l}-0.226^{* * *} \\
(0.059)\end{array}$ & $\begin{array}{l}-0.292^{* * *} \\
(0.064)\end{array}$ \\
\hline Asset index & $\begin{array}{l}0.133 \\
(0.235)\end{array}$ & $\begin{array}{l}-0.106 \\
(0.161)\end{array}$ & $\begin{array}{l}0.114 \\
(0.125)\end{array}$ & $\begin{array}{l}0.167 \\
(0.226)\end{array}$ & $\begin{array}{l}0.071 \\
(0.159)\end{array}$ \\
\hline Age of firm (years) & $\begin{array}{c}-0.048^{*} \\
(0.029)\end{array}$ & $\begin{array}{l}-0.020 \\
(0.022)\end{array}$ & $\begin{array}{l}-0.021 \\
(0.016)\end{array}$ & $\begin{array}{l}-0.032 \\
(0.035)\end{array}$ & $\begin{array}{l}-0.045^{* *} \\
(0.018)\end{array}$ \\
\hline Firm is formal $(=1)$ & $\begin{array}{l}0.366 \\
(0.333)\end{array}$ & $\begin{array}{l}0.130 \\
(0.310)\end{array}$ & $\begin{array}{l}0.272 \\
(0.194)\end{array}$ & $\begin{array}{l}0.491 \\
(0.357)\end{array}$ & $\begin{array}{l}0.254 \\
(0.322)\end{array}$ \\
\hline No siblings alive & & & Ref. & Ref. & Ref. \\
\hline 1 to 3 siblings alive & & & $\begin{array}{l}-0.354 \\
(0.539)\end{array}$ & $\begin{array}{l}0.460 \\
(0.707)\end{array}$ & $\begin{array}{l}-2.182^{* * *} \\
(0.590)\end{array}$ \\
\hline 4 to 7 siblings alive & & & $\begin{array}{l}-1.048^{* *} \\
(0.502)\end{array}$ & $\begin{array}{l}0.014 \\
(0.733)\end{array}$ & $\begin{array}{l}-1.961^{\text {*** }} \\
(0.546)\end{array}$ \\
\hline 8 and more siblings alive & & & $\begin{array}{l}-1.137 * * \\
(0.556)\end{array}$ & $\begin{array}{l}0.240 \\
(0.800)\end{array}$ & $\begin{array}{l}-2.598^{* * *} \\
(0.619)\end{array}$ \\
\hline Risk aversion index & & & $\begin{array}{l}-0.463^{* * *} \\
(0.137)\end{array}$ & $\begin{array}{l}-0.243 \\
(0.163)\end{array}$ & $\begin{array}{l}-0.017 \\
(0.243)\end{array}$ \\
\hline Age of tailor (years) & & & $\begin{array}{l}-0.034 * * \\
(0.013)\end{array}$ & $\begin{array}{l}-0.037 \\
(0.025)\end{array}$ & $\begin{array}{l}-0.014 \\
(0.016)\end{array}$ \\
\hline Tailor is household head $(=1)$ & & & $\begin{array}{l}-0.370^{*} \\
(0.227)\end{array}$ & $\begin{array}{l}0.346 \\
(0.328)\end{array}$ & $\begin{array}{l}-0.634 \\
(0.487)\end{array}$ \\
\hline Primary completed $(=1)$ & & & $\begin{array}{l}0.301 \\
(0.191)\end{array}$ & $\begin{array}{l}0.727^{* *} \\
(0.343)\end{array}$ & $\begin{array}{l}0.240 \\
(0.292)\end{array}$ \\
\hline Married (=1) & & & $\begin{array}{l}0.167 \\
(0.209)\end{array}$ & $\begin{array}{l}0.326 \\
(0.329)\end{array}$ & $\begin{array}{l}0.504 \\
(0.360)\end{array}$ \\
\hline Mossi (=1) & & & & $\begin{array}{l}-0.520 \\
(0.396)\end{array}$ & $\begin{array}{l}-0.765^{* *} \\
(0.338)\end{array}$ \\
\hline No of brothers outside $\mathrm{HH}$ of origin & & & $\begin{array}{l}-0.010 \\
(0.037)\end{array}$ & $\begin{array}{l}-0.007 \\
(0.061)\end{array}$ & $\begin{array}{l}-0.095^{* *} \\
(0.042)\end{array}$ \\
\hline No of sisters outside $\mathrm{HH}$ of origin & & & $\begin{array}{l}0.054 \\
(0.038)\end{array}$ & $\begin{array}{l}0.016 \\
(0.071)\end{array}$ & $\begin{array}{l}0.091 \\
(0.066)\end{array}$ \\
\hline Father primary completed $(=1)$ & & & $\begin{array}{l}0.311 \\
(0.372)\end{array}$ & $\begin{array}{l}0.738 \\
(0.524)\end{array}$ & $\begin{array}{l}0.098 \\
(0.369)\end{array}$ \\
\hline Mother primary completed $(=1)$ & & & $\begin{array}{l}-0.479 \\
(0.524)\end{array}$ & $\begin{array}{l}-0.654 \\
(0.658)\end{array}$ & $\begin{array}{l}-0.592 \\
(0.475)\end{array}$ \\
\hline Father is/was farmer $(=1)$ & & & $\begin{array}{l}0.147 \\
(0.224)\end{array}$ & $\begin{array}{l}0.601 \\
(0.427)\end{array}$ & $\begin{array}{l}0.411 \\
(0.329)\end{array}$ \\
\hline Father is/was indep. non-agric. $(=1)$ & & & $\begin{array}{l}0.512^{* *} \\
(0.213)\end{array}$ & $\begin{array}{l}-0.079 \\
(0.384)\end{array}$ & $\begin{array}{l}0.148 \\
(0.389)\end{array}$ \\
\hline
\end{tabular}

Table continues next page. 
Table S5: (... continued)

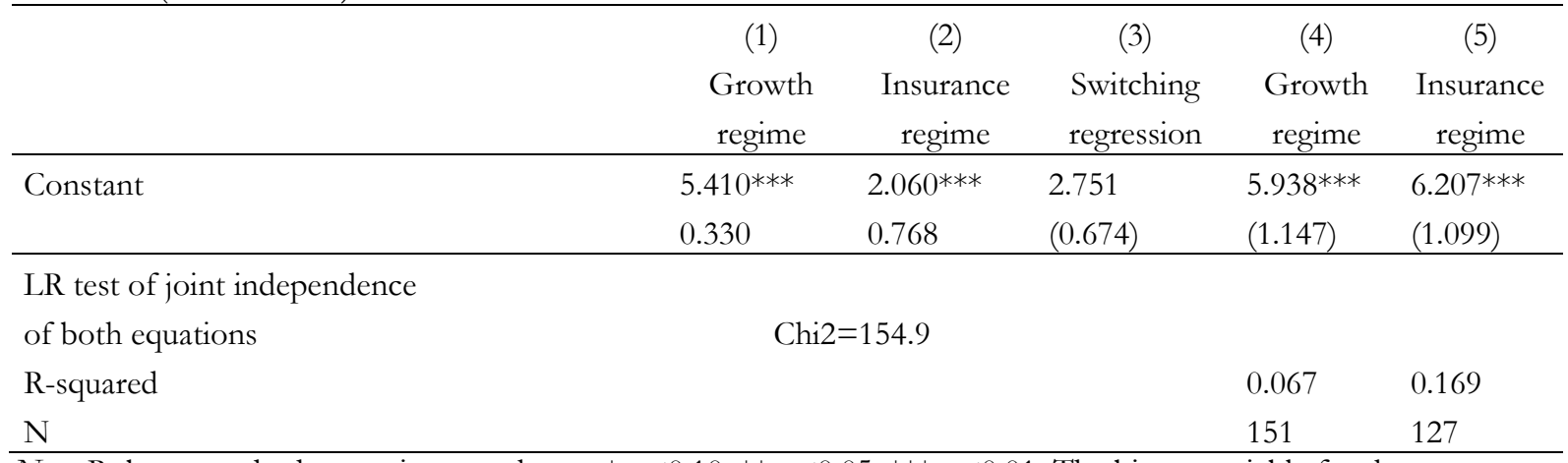

Note: Robust standard errors in parentheses. ${ }^{*} \mathrm{p}<0.10,{ }^{* *} \mathrm{p}<0.05, * * * \mathrm{p}<0.01$. The binary variable for the Mossi does not converge in the switching regression.

Source: Own data, collected in January 2011 and 2012 in Ouagadougou, Burkina Faso. 